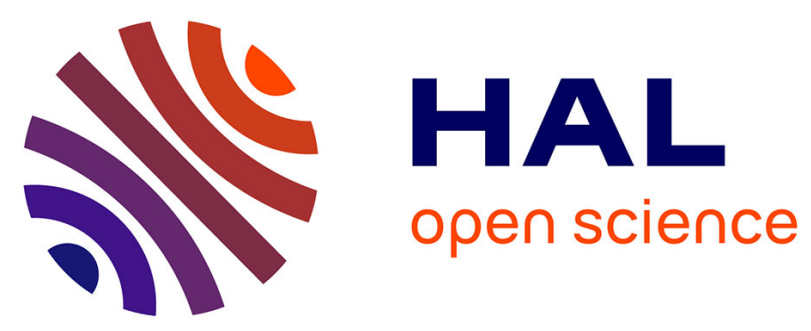

\title{
Removal of Hydrophobic Volatile Organic Compounds in an Integrated Process Coupling Absorption and Biodegradation - Selection of an Organic Liquid Phase
}

Guillaume Darracq, Annabelle Couvert, Catherine Couriol, Abdeltif Amrane, Pierre Le Cloirec

\section{To cite this version:}

Guillaume Darracq, Annabelle Couvert, Catherine Couriol, Abdeltif Amrane, Pierre Le Cloirec. Removal of Hydrophobic Volatile Organic Compounds in an Integrated Process Coupling Absorption and Biodegradation - Selection of an Organic Liquid Phase. Water, Air, and Soil Pollution, 2012, 223 (8), pp.4969-4997. 10.1007/s11270-012-1251-0 . hal-00827983

\section{HAL Id: hal-00827983 https://hal.science/hal-00827983}

Submitted on 31 May 2013

HAL is a multi-disciplinary open access archive for the deposit and dissemination of scientific research documents, whether they are published or not. The documents may come from teaching and research institutions in France or abroad, or from public or private research centers.
L'archive ouverte pluridisciplinaire HAL, est destinée au dépôt et à la diffusion de documents scientifiques de niveau recherche, publiés ou non, émanant des établissements d'enseignement et de recherche français ou étrangers, des laboratoires publics ou privés. 
1 Removal of hydrophobic Volatile Organic Compounds

2 in an integrated process coupling Absorption and

3 Biodegradation - Selection of an organic liquid phase

4 Guillaume Darracq $^{1,2}$, Annabelle Couvert ${ }^{1,2}$, Catherine Couriol ${ }^{1,2}$, Abdeltif Amrane $^{1,2} *$, Pierre Le

5 Cloirec $^{1,2}$

$6{ }^{1}$ Ecole Nationale Supérieure de Chimie de Rennes, CNRS, UMR 6226, Avenue du Général Leclerc,

7 CS 50837, 35708 Rennes Cedex 7, France

$8 \quad{ }^{2}$ Université européenne de Bretagne

9

10 


\begin{abstract}
Since usual processes involve water as absorbent, they appear not always really efficient for the treatment of hydrophobic VOC. Recently, absorption and biodegradation coupling in a two-phase partitioning bioreactor (TPPB) proved to be a promising technology for hydrophobic compound treatment. The choice of the organic phase, the nonaqueous phase liquid (NAPL) is based on various parameters involved in both steps of the process, hydrophobic VOC absorption in a gas-liquid contactor, and biodegradation in the TPPB. VOC solubility and diffusivity in the selected NAPL, as well as NAPL viscosity, seems to be the main parameters during the absorption step, while biocompatibility, namely the absence of toxic effect of the NAPL towards microorganisms, non-biodegradability and VOC partition coefficient between NAPL and water were revealed as the key factors during the biodegradation step. The screening of the various NAPL available in the literature highlighted two families of compounds matching the required conditions for the proposed integrated process, silicone oils and ionic liquids.
\end{abstract}

Key words: Hydrophobic VOC; Absorption; Two-phase partitioning bioreactor; Non-aqueous phase liquid; Silicone oils; Ionic liquids.

\title{
Contents
}

1. Introduction

2. The considered integrated process

3. Absorption of hydrophobic VOC

3.1. Mass transfer theory

3.2. Henry's constants

3.3. Global mass transfer coefficient

3.4. Diffusion coefficient

3.5. NAPL viscosity

4. Regeneration of the Non-Aqueous Phase Liquid by biodegradation

4.1. Two-phase partitioning bioreactor (TPPB)

4.2. Toxicity of NAPL towards microorganisms or biocompatibility

4.3. Miscibility of NAPL in water

4.4. Biodegradability of NAPL

4.5. Parameters characteristic of VOC mass transfer in TPPB

\section{Screening and choice of the NAPL}

5.1. Silicone oils

5.2. Ionic liquids

\section{Conclusion}




\section{Introduction}

With the matter of Global warming owing to the greenhouse effect, the treatment of atmospheric emission, including Volatile Organic Compounds, has become an ecological and economic stake. Volatile Organic Compounds are organic compounds, in which hydrogen can be substituted by other compounds such oxygen, phosphor, or halogens with a vapour pressure superior to $10 \mathrm{~Pa}$ in standard conditions $\left(20^{\circ} \mathrm{C}\right.$ and $1 \mathrm{~atm}$ ) (Le Cloirec 1998). These molecules are produced by some process industries, such as refineries, synthetic flavouring or painting factories (Revah and Morgan-Sagastume 2005), and can also be naturally generated during biological degradation.

VOC can be treated by several methods, including destructive (incineration, biofiltration and catalytic oxidation) and non-destructive (absorption, adsorption, condensation and membrane filtration) processes. The selection of the most appropriate method is based on the gas flow rate and the pollutant concentration (Fig. 1). Absorption is an interesting method, owing to the low pressure drop generated and the low maintenance needed, contrarily to membrane processes that require high working pressures to treat low gas flow rates (Fig. 1). An emerging technology like photochemical oxidation shows high efficiency but is also high energy-consuming; moreover, VOC can be a poison for the catalyst used (Muñoz et al. 2007). Each technology shows limitations and advantages.

Hydrophilic compounds like hydrogen sulphide or ammonium are usually treated by chemical scrubbing (Roustan. 2003; Biard et al. 2009; Biard et al. 2010). Water soluble VOC can also be removed by biological processes such as biofilters, biotrickling filters or bioscrubbers (Kennes et al. 2009) for low concentrations and high gas flow rates. Biological treatments have gained support as an effective and economical option for the treatment of hydrophilic VOC in gas effluents (Burgess et al. 2001).

Even if some pollutants such as hydrocarbons, alcohols and esters are consumed by specific microbial consortium (Ottengraf et al. 1986), several chemical or biological factors can result in an absence of degradation (Fewson 1991). Owing to VOC toxicity, their concentration in the aqueous phase should be below the inhibitory threshold for microorganisms. At a chemical level, the shape, the charge or the size of the molecule, a low concentration and solubility in water or a biosorption phenomenon are factors that can stave off biodegradation, leading to its classification as a recalcitrant process (Alexander 1973). At a biological level, the lag-time, the lost of genetic potential or the inability to metabolise pollutants are factors that can engender non-degradation (Le Cloirec 1998).

However, this kind of technology implies an aqueous system containing nutrients (Trinci 1969), which limits the usefulness of these methods in the case of hydrophobic VOC. Among these latter, dimethyl disulphide (DMDS) and dimethyl sulphide (DMS) are produced during biological decay, combustion of fossil fuels and organic matter, as well as sea spray. Both pollutants show low water solubility, 2.5 and $20.5 \mathrm{mg} . \mathrm{L}-1$, a characteristic odour and low olfactory thresholds: 2.50 and $14.00 \mu \mathrm{g} . \mathrm{m}-3$ for DMS and DMDS (Hartikainen et al. 2002). Two main ways are usually selected to remove organic sulphur compounds (hydrophilic and hydrophobic), the chemical one (charcoal adsorption, incineration and chemical washing) and the biological one (biodegradation) (Burgess et al. 2001; Cha et al. 1999).

Some other compounds are also poorly soluble, for example aromatic compounds, such as toluene. Thus, chemical techniques are generally preferred for complex VOC mixtures or for products that can be damaged by strong oxidants (Biard et al. 2010). 
The aim of this review is to discuss the choice of the most appropriate liquid absorbent to solubilise the model hydrophobic odorous VOC selected, namely toluene, DMS and DMDS (Table 1). The absorbent should be biocompatible towards microorganisms and not biodegradable in view of its recycling in the whole process. The choice of the liquid absorbent as a function of the requirements of each step of the proposed integrated process is examined in this paper.

\section{The considered integrated process}

In order to remove hydrophobic compounds such as aromatic, sulphur and/or odorous products, a possible process consists of coupling absorption and biodegradation in a two-phase partitioning bioreactor (TPPB), allowing the regeneration of the absorbent phase. To increase the gas-liquid mass transfer of hydrophobic compounds, the absorbent is a non-aqueous phase liquid (Déziel et al. 1999). A schematic approach of the multistep process is presented in Fig. 2 (Césario et al. 1998). The first step consists of VOC absorption in a NAPL and the second of NAPL regeneration by VOC biodegradation (TPPB). Both steps are discussed in this review to select the most appropriate NAPL. A two steps process is proposed instead of only a TPPB operation mode involving absorption and biodegradation in the same process unit (such as a stirred tank), since kinetics of VOC absorption on the one hand and VOC biodegradation on the other hand are expected to be largely different. The differentiation of the two steps would therefore lead to more flexibility and would helpful for the driving of the process and its control.

In the integrated process, the target compounds (VOC) are absorbed in an NAPL (Daugulis and Boudreau 2003); after VOC biodegradation in an emulsion organic/aqueous phase, the NAPL can be regenerated and recycled in the gas-liquid contactor after a separation step from the aqueous phase. The bioreactor is characterised by a water-immiscible NAPL loaded with VOC and an aqueous phase containing microorganisms. In other words, VOC-trapping is achieved in an absorption contactor (wherein the NAPL is the absorbent phase), which is followed by a bioreactor (Daugulis 2001).

The NAPL plays two functions:

- The role of absorbent in the gas-liquid contactor in order to increase mass transfer between the gas and the liquid phase, since the hydrophobic VOC solubility is more significant in the NAPL than in water.

- The role of storage phase for toxic or hydrophobic substrates in the bioreactor, allowing maintaining sub-inhibitory concentrations in the aqueous phase.

Several works dealing with two-phase partitioning bioreactor (TPPB) (Déziel et al. 1999; Daugulis 2001; Yeom and Daugulis 2000; Malinowski 2001; Mahanty et al. 2008) are available in the literature. Since the mid-seventies, bioconversion of toxic and/or hydrophobic compounds has been investigated in multiphase bioreactor systems (Table 2).

The considered two steps process presents several advantages compared to other biotechnologies (bioscrubbers or biofilters) (Yeom and Daugulis 2000); advantages and drawbacks are discussed in Table 3. Among them, biofilters are the most commonly used processes for the removal of gaseous effluents loaded with low VOC concentrations. For example, total toluene removal $\left(164.4 \mathrm{~g} \cdot \mathrm{m}^{-3} \cdot \mathrm{h}^{-1}\right)$ using a perlite filter bed involving fungi was recorded (Estévez et al. 2005), whereas Pernafeta-Boldù et al. (Pernafeta-Boldù et al. 2008) recorded a removal efficiency of $62 \%$ (corresponding to a removed toluene gaseous flux of $30 \mathrm{~g} \cdot \mathrm{m}^{3} \cdot \mathrm{h}^{-}$ $\left.{ }^{1}\right)$. Besides, significant DMS (dimethylsulphide) purification capacities were also recorded using biofilters by 
Zhang et al. (Y. Zhang et al. 2007) $\left(0.20 \mathrm{~g} \mathrm{DMS} \cdot \mathrm{m}^{-3} \cdot \mathrm{h}^{-1}\right.$ or $\left.0.10 \mathrm{gS} \cdot \mathrm{m}^{-3} \cdot \mathrm{h}^{-1}\right)$, and by Shu and Chen (Shu and Chen 2009) (90 gS. $\mathrm{m}^{-3} \cdot \mathrm{h}^{-1}$ ).

Similarly to toluene, experimental conditions have also an effect on the removal capacity, namely the considered microorganisms (fungi, pure culture, mixed culture...), the relative humidity of the gas phase, the residence time and the environmental conditions.

The main downsides of biofiltration are:

- the long starting period corresponding to cell proliferation in the bed (Daugulis 2001),

- the sensibility of the process versus a lot of environmental conditions (Kennes et al. 2009),

- the biofilter volume and hence its built-up area.

Water is not an adequate absorbent phase owing to substrate hydrophobicity. Indeed, mass transfer is the rate-limiting step in biological processes due to the low VOC solubility in water (Césario et al. 1997a). Therefore, an NAPL can be selected to improve mass transfer (Guieysse et al. 2008) and then to reduce the residence time in the gas-liquid contactor. Indeed, a large amount of hydrophobic compounds can be stored in an organic phase, the NAPL, which can be considered as a pollutant tank that can be employed to release low hydrophobic substrate concentrations or non-toxic inhibitory for cells contained in the aqueous phase. Moreover, various compounds such as PAH mixture, mutagenic or carcinogenic pollutants, hydrophobic, toxic products, but also mixtures of hydrophobic and hydrophilic VOC can be treated by this kind of reactor (Table 2), since the liquid phase can consist of the NAPL alone or a water/NAPL emulsion.

In order to optimise the process, many criteria must be taken into account. Among them, the choice of the organic phase is one of the key factors.

\section{Absorption of hydrophobic VOC}

\subsection{Mass transfer theory}

The first process step concerns the absorption of hydrophobic VOC in the NAPL. The thermodynamic equilibrium between the gas and liquid phases, as well as mass transfer kinetics from the gaseous phase to the liquid phase, has to be considered (F. Heymes et al. 2007; Hernández et al. 2011). Among the various technical ways usually applied to achieve contact between both phases (gas and liquid), packed columns can be chosen due to the low pressure drop they imply and the relatively high interfacial area they offer.

Absorption requires knowledge of hydrodynamic parameters like pressure drop and liquid hold up. These variables depend on the geometry of the system (dimensions of the apparatus), the type of column packing (shape, size, porosity, specific area, etc), the flow rates and the fluid characteristics under the operating conditions (temperature, pressure, physico-chemical properties, droplet distribution). Once the hydrodynamic parameters have been selected and optimised, mass transfer considerations must be discussed.

Moreover, the rate-limiting step is the mass transfer rate of hydrophobic gaseous compounds to the aqueous phase, so that performing the absorption step in a gas-liquid contactor can appear especially relevant. Owing to the lower Henry's constant of hydrophobic VOC in NAPL than in water, the use of NAPL instead of water is preferable (Dumont and Delmas 2003).

Gas-liquid mass transfer can be described by Eq. 1 (Roustan. 2003). 
$\frac{d C_{L}}{d t}=K_{L} a C^{*}-C_{L}$

Where $C_{L}$ and $C^{*}$ are the VOC concentrations in the liquid phase (NAPL) and in equilibrium with the gas phase respectively, and $K_{L}$ is the overall VOC mass transfer coefficient in the liquid phase.

In 1924, Lewis and Whitman described the boundary film model to characterise gas-liquid mass transfer. Using Eq. 1 describing the physical mass transfer between the gas and the liquid phases and Eq. 2 related to the mass balance in the packed column, Eq. 3 can be deduced and highlights the mass transfer key factors, the Henry's constant $H$ (mol.m ${ }^{-3}$ gas $/ \mathrm{mol} . \mathrm{m}^{-3}$ liquid), the overall liquid mass transfer coefficient $K_{L}$ (m.s ${ }^{-1}$ ), and the volumetric interfacial area $a\left(\mathrm{~m}^{2} \cdot \mathrm{m}^{-3}\right)$.

$Q_{G} \mathbf{C}_{G, \text { in }}-C_{G, \text { out }} \bar{\equiv} Q_{L} \mathbf{C}_{L, \text { out }}-C_{L, \text { in }}$,

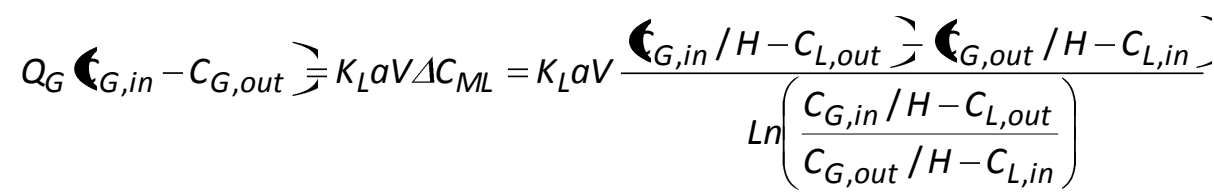

With $Q_{G}$ and $Q_{L}$ the gas and liquid volumetric flow rates $\left(\mathrm{m}^{3} \cdot \mathrm{s}^{-1}\right)$, and $\Delta C_{M L}$, the average logarithmic concentration of the pollutant in the liquid phase $\left(\mathrm{mol} . \mathrm{m}^{-3}\right)$.

Regarding the terms of theses equations, it appears that the physical properties of the NAPL and the VOC (density, viscosity, gas diffusivity and solubility in the liquid phase) influence the performances of absorption.

Owing to the higher hydrophobic VOC solubility in a NAPL than in water, their removal can be significantly increased due to a higher driving force between gas and NAPL (Césario et al. 1998).

\subsection{Henry's constants}

Besides hydrodynamic parameters, like gas velocity and column dimensions, mass transfer depends on VOC equilibrium between both phases and mass transfer velocity. The former factor is linked to VOC solubility in the NAPL, which can be deduced from the Henry's equation (Eq. 4):

$C_{G}=H C_{L}$

With $C_{G}$ and $C_{L}$ the $\mathrm{VOC}$ concentrations in the gas and the liquid phases respectively, and $H$ the dimensionless Henry's constant.

Hence, the lower the Henry's constant, the better the gas-liquid mass transfer. For hydrophobic VOC, the $H$ values in water are high owing to their low solubility (Table 4). As a consequence, the amount of VOC likely to be transferred in the liquid phase is low, and the maximum solubility is rapidly reached, leading to a nil driving force $\left(\frac{C_{G}}{H}-C_{L}\right)$, so that mass transfer is stopped.

If no chemical reaction occurs, a more appropriate absorbent phase must be chosen, i.e. a liquid phase in which Henry's constant values of the targeted hydrophobic VOC are lower. Henry's constant values of toluene, DMS and DMDS in different NAPL are collected in Table 5, and compared to those in water, showing the higher affinity of the VOC for NAPL than for water. 
Darracq et al. (Darracq et al. 2010c) showed that the Henry's constant $\left(H^{\prime \prime}\right.$ in Pa. $\left.\mathrm{m}^{3} \cdot \mathrm{mol}^{-1}\right)$ of DMDS and toluene in a silicone oil/water emulsion can be related to the volume fraction of NAPL $x$ following Eq. 5:

$\frac{1}{H^{\prime \prime} \text { voc }_{\text {emulsion }}}=\frac{1}{H^{\prime \prime} \text { vOC }_{\text {Solvent }}} x+\frac{1}{H^{\prime \prime} \text { voc }_{\text {Wtater }}}(1-x)$

However, experimental values given in Table 6 show that the comparison between 100\% NAPL and a water/NAPL emulsion is not easy to establish since no clear trend can be deduced. Liquid or pollutant properties on one hand and the used gas-liquid contactor system on the other hand most likely account for the differences between the considered systems, 100\% water, 100\% NAPL and water/NAPL emulsion.

\subsection{Global mass transfer coefficient}

In addition to the Henry's constant, other parameters have an impact on mass transfer. Among them, the local liquid and gas mass transfer coefficients $\left(k_{L}\right.$ and $\left.k_{G}\right)$, as well as the global liquid and gas mass transfer coefficients $\left(K_{L}\right.$ and $K_{G}$ ). Eqs. 6 and 7 describe the relation between these coefficients (Roustan. 2003).

$\frac{1}{K_{L}}=\frac{1}{k_{L}}+\frac{1}{H k_{G}}$

$\frac{1}{K_{G}}=\frac{1}{k_{G}}+\frac{H}{k_{L}}$

Values of $K_{L} a$ are reported in Table 6, allowing the comparison between absorption in water and in NAPL. Variations of $K_{L} a$ values can be observed, depending on the hydrodynamic conditions and the design of the gas-liquid contactor used (Bourgois et al. 2009). Nevertheless, whereas Bourgeois et al. (Bourgois et al. 2009) worked with a cables-bundle scrubber, while other authors (Dumont et al. 2006; Darracq et al. 2010c) used a bubble batch reactor, very close mass transfer values were obtained.

However, few data concerning toluene, DMS or DMDS are available in the literature. $K_{L} a$ values have been also measured in water/NAPL emulsions (Césario et al. 1997a; Rodriguez et al. 2001; Clarke and Correia 2008). Previous works dealing with oxygen mass transfer in water/NAPL emulsions showed that the volume fraction of NAPL in the emulsion have an effect on $K_{L} a$ values (MacMillan and Wang 1987; Rols et al. 1990; Césario et al. 1997a; Dumont et al. 2006; Quijano et al. 2010b).

\subsection{Diffusion coefficient}

In addition to the Henry's constants, two parameters have an impact on the global mass transfer coefficient, the film thickness and the diffusion coefficient. Whatever the theoretical model, film, penetration or surface-renewal theories, Dumont and Delmas (Dumont and Delmas 2003) showed that the VOC diffusion coefficient $\left(D_{L}\right)$ is an important parameter. According to Heymes et al. (F Heymes et al. 2006), the diffusion coefficient has a strong influence on absorption efficiency. In short, the diffusion coefficient in the liquid absorbent is a key parameter to understand complex mass transfer phenomena and to design mass transfer devices. 
In 2001, Fei and Bart (Fei and Bart 2001) used the group contribution method to determine this coefficient. However, this method gives reliable results only for binary and low viscous systems. Bourgois et al. (Bourgois et al. 2009) showed that some widely used empirical correlations, like the Scheibel's correlation (Scheibel 1954) and the Wilke and Chang's correlation (Wilke and Chang 1955), are inappropriate for the estimation of liquid diffusivities in viscous solvents. The results displayed in Table 7 concern mainly toluene, while there is a lack of information dealing with volatile sulphur compounds. Liquid diffusivities in some organic solvents are often ten times lower than in water.

\subsection{NAPL viscosity}

In addition to the diffusion coefficient, the NAPL viscosity plays a role on the hydrodynamic behaviour of the column, on the diffusion coefficient of the selected VOC. This parameter influences hydrodynamics and gas-liquid mass transfer. A low viscosity minimises the thickness of the interface between both phases and increases the diffusion kinetics in this layer ( $F$ Heymes et al. 2006). Moreover, viscosity has an effect on the Henry's constant (Table 5). Indeed, for a given temperature, an increase of the viscosity results in an increase of the Henry's constant.

To conclude on these considerations, the physico-chemical properties of the NAPL play a role on hydrodynamics (viscosity for example) and hence on mass transfer coefficients (absorption capacity and absorption rate). The selected NAPL should therefore comply with the following criterion, a low Henry's constant of the considered VOC.

\section{Regeneration of the Non-Aqueous Phase Liquid by biodegradation}

\subsection{Two-phase partitioning bioreactor (TPPB)}

After VOC mass transfer from the gas phase to a NAPL, VOC degradation is carried out in a two-phase partitioning bioreactor (TPPB), which consists of a stirred bioreactor filled with two immiscible liquid phases, leading to the formation of an emulsion, increasing the interfacial area. This concept is based on the selective partitioning of the pollutant between water and NAPL. VOC biodegradation performances depend on the presence and the assimilation potential of various microbial agents such as bacteria, fungi or yeasts in the aqueous phase (Rehmann and Daugulis 2007). In a TPPB, hydrophobic (or toxic) compounds are delivered to the aqueous phase at sub-inhibitory levels for microorganisms in case of toxic compounds or at the solubilisation limit in case of hydrophobic compounds, related to the microbial demand.

Déziel et al. (Déziel et al. 1999) proposed three mechanisms for hydrophobic or toxic compounds consumption:

1. The substrate is removed after its solubilisation in an aqueous phase. The degradation rate is function of the mass transfer rate from the organic to the aqueous phase. Efroymson and Alexander (Efroymson and Alexander 1991) as well as Bouchez et al. (Bouchez et al. 1997) showed that VOC biodegradation rate in the organic phase is higher than mass transfer rate between both phases. Therefore, biodegradation only occurs in the aqueous phase and is governed by substrate equilibrium between both liquid phases. 
2. VOC removal takes place at the liquid-liquid (organic-aqueous) interface. VOC can be directly assimilated at the interface after biofilm development between both liquid phases (Guieysse et al. 2001). Muñoz et al. (Muñoz et al. 2006) showed that cells are in direct contact with the organic phase since VOC concentration is more significant near the interface. This phenomenon was confirmed by Efroymson and Alexander (Efroymson and Alexander 1991) who reported bacterial accumulation at the interface and a decrease of cell growth in the aqueous phase.

3. If the microorganisms are surfactant- or emulsifier-producers, there is formation of small droplets or micelles, leading to a reduction of the surface tension of the aqueous phase and an increase of the interfacial area until microemulsion formation (Desai and Banat 1997). This phenomenon improves substrate availability for microorganisms mainly located at the organic-aqueous interface and hence improves VOC removal.

Some interactions can be considered as key factors in the process, like VOC / NAPL, NAPL / microorganisms, or water / VOC. Some authors consider that TPPBs should be used with microorganisms able to consume pollutants directly at the NAPL-water interface (Guieysse et al. 2001). This interfacial area has a significant role in the uptake mechanism. Indeed, Ascon-Cabrera and Lebeault (Ascon-Cabrera and Lebeault 1995) showed that the degradation rate increases after cell adhesion to the interface of NAPL, i.e. when the interfacial area increases. This parameter, which can be considered as a key factor in the liquid-liquid mass transfer step, is affected by the operating conditions like the stirring speed and the type of impeller (if used), the volume fraction of NAPL in the emulsion, or the presence of possible chemical reactions in the aqueous phase. For instance, MacLeod and Daugulis (MacLeod and Daugulis 2005) showed an increase of the rate of PAH (Polycyclic Aromatic Hydrocarbon) degradation linked to an increase of the stirring speed (84 and $150 \mathrm{mg} \cdot \mathrm{L}^{-1}$.day ${ }^{-1}$ at 300 and $500 \mathrm{rpm}$ respectively). These authors also proved that oxygen is not the limiting factor in the degradation step (MacLeod and Daugulis 2005), even if this assessment should be considered with caution, since it is most likely related to VOC concentration and VOC Henry's constant. Otherwise, Ascon-Cabrera and Lebeault (Ascon-Cabrera and Lebeault 1993) showed that the NAPL volume in the emulsion has a significant effect on the microorganism growth; for a silicone oil/water system the highest specific growth rates are recorded for stirring speed ranging between 500 and $700 \mathrm{rpm}$ and a volume fraction of NAPL ranging from 20 to $40 \%$.

There is a general agreement that the major part of hydrophobic VOC uptake is achieved at the interface of both liquid phases due to the adherence of cells at the interface (Ascon-Cabrera and Lebeault 1993; Déziel et al. 1999; Muñoz et al. 2006). The following steps can be considered during hydrophobic pollutant removal in a TPPB (Déziel et al. 1999):

1. The substrate is consumed in the aqueous phase.

2. After an increase of the biomass, cells become more hydrophobic and can adhere to the NAPL-water interface where substrate concentration is more abundant.

3. Then, cell growth and attach at the interface, namely on the NAPL droplet surface. The substrate amount in the aqueous phase is nil when the biodegradation rate at the interface is higher than the mass transfer rate.

4. In addition to biomass growth, substrate consumption can induce biosurfactant production, which decreases the surface tension and increases the interfacial area. This phenomenon has an effect on the microorganism growth and the mass transfer rate.

5. Finally, a stable emulsion (small droplets of NAPL in water) appears, driving to high mass transfer performances.

Besides pollutants should be metabolised by activated sludge, the system should fulfil several characteristics. A method for the choice of the most appropriate NAPL to be implemented in a TPPB has 
been proposed by several authors. The NAPL should be water-immiscible, safe, chemically stable, biocompatible (non-toxic towards the microbial community), non-biodegradable and should not have a too high specific VOC partition coefficient between NAPL and water (Déziel et al. 1999; Muñoz et al. 2006; Bruce and Daugulis 1991; Quijano et al. 2009). Experiments carried out with various microorganisms and NAPL are listed in Table 8. These different parameters are discussed hereafter.

\subsection{Toxicity of NAPL towards microorganisms or biocompatibility}

The metabolic activity of microorganisms regulates the mass transfer rate from the organic phase to the aqueous phase or in other words, this system is self-regulatory (Collins and Daugulis 1997b). The NAPL should not interfere in the system, but improve mass transfer and biodegradation rate.

Otherwise, the NAPL should not be toxic towards microorganisms. The literature relates that NAPL preferentially accumulates on the cytoplasmic membrane of cells and causes damages, resulting in the destruction of the microorganism; the accumulation of lipophilic compounds in the membrane has considerable effects on its structural and functional properties (De Bont 1998; Sardessai and Bhosle 2002). According to Brink et al. (Brink et al. 1988) changes in permeability, enzyme inhibition, protein deactivation, or a breakdown of transport mechanisms can be observed after contact between microorganisms and a NAPL.

In order to examine the growth-potential of microorganisms in the presence of the NAPL, two parameters are commonly taken into account, NAPL polarity and NAPL solubility in water, through the octanol/water partition coefficient $P$ or Kow (Bruce and Daugulis 1991; Ogino et al. 1999) (Eq. 8):

$\log$ Kow $=\log P=\log \left(\frac{[\text { Solvent }]_{\text {Oc tanol }}}{[\text { Solvent }]_{\text {water }}}\right)$

The partition coefficients of several NAPL that can be implemented in two-phase partitioning bioreactors are collected in Table 9.

Log Kow characterizes the resistance of microorganisms, and below a critical log Kow value, growth cannot occur (Table 10). This parameter is commonly accepted as the best indicator of NAPL biocompatibility (Laane et al. 1985; Laane et al. 1987; Inoue and Horikoshi 1991).

For instance, Pseudomonas aeruginosa LST-03 can grow in the presence of various NAPL having log Kow superior to 2.9 (critical value of log Kow). Indeed gram-negative bacteria like the Pseudomonas genus are assumed to be more NAPL tolerant than gram-positive bacteria. This resistance can be explained by the presence of an additional outer membrane made up of phospholipids and lipopolysaccharides if compared to gram-positive bacteria (Sardessai and Bhosle 2002). The presence of the NAPL in the lipid bilayer results in an increase of the fluidity leading to an inactivation of the membrane-embedded proteins, such as ion pumps and ATPases, or an increase of the membrane permeability, which is considered as the main reason for cell death (Heipieper et al. 2007; Osborne et al. 1990; Sikkema et al. 1995). The relationship linking the partition coefficient and biocompatibility is based on the assumption that the octanol/water system provides an adequate description of the hydrophobic interactions occurring in a biological system (Bruce and Daugulis 1991). 
There is a general agreement that the log Kow critical value is 4.0 to determine the biocompatibility, while below this value the NAPL is toxic towards most of the microorganisms (Déziel et al. 1999; Arriaga et al. 2006; Collins and Daugulis 1997a, 1999a; Hayachi et al. 2003; Matsumoto et al. 2004).

According to their toxicity, a lot of NAPL can be used in a TPPB containing pure cultures (autotrophic and heterotrophic microorganisms) or mixed cultures including activated sludge.

\subsection{Miscibility of NAPL in water}

The NAPL miscibility in water should be the lowest possible in view of a readily separation in the subsequent settler. The addition of an immiscible phase leads to an emulsion, resulting in an increase of the interfacial area and hence enhances VOC transfer to the aqueous phase. However, one of the drawbacks of the process is a possible biosurfactants production, which can induce an increase of emulsion stability and hence more difficulties to recover the organic phase during the separation step. A low NAPL solubility would also allow to limit the effects of potential toxicity towards microorganisms.4.4. Biodegradability of NAPL

In view of their recycling, biodegradable NAPL should be avoided while it is the case for most of them (Table 9).

Table 9 highlights the difficulty to select a non-biodegradable NAPL. Van der Meer et al. (Van der Meer et al. 1992) indicated that in the presence of a microbial consortium, a limited number of NAPL can be chosen. Indeed, after a lag (or adaptation) time, almost all the organic compounds are attacked by microorganisms. Muñoz et al. (Muñoz et al. 2007) consider that it is difficult to predict the stability of a given NAPL in the presence of microorganisms on long-term, owing to a possible emergence of microorganisms able to degrade the NAPL. Besides its recycling is no longer possible, NAPL biodegradability can lead to a competition between substrates, the NAPL and VOC.

\subsection{Parameters characteristic of liquid-liquid VOC mass transfer in TPPB}

Since biodegradation occurs in the aqueous phase, mass transfer between the NAPL and the aqueous phase is an important parameter. Several authors studied mass transfer between a gas phase and a water/ NAPL mixture (Césario et al. 1998; Muñoz et al. 2007; Dumont et al. 2006). The concentration gradient between both phases can be described using Eq. 1 and Fig. 3. However, the interface concentration $\left(C^{*}\right)$ cannot be measured, and hence is deduced from the specific VOC partition coefficient (Césario et al. 1997a; Tudose and Apreotesei 2001; Yeom and Daugulis 2001a) (Eqs. 9 and 10):

$\frac{d C_{N A P L}}{d t}=K_{N A P L}^{N A P L} / W_{a} \mathbf{C}_{N A P L}-K_{N A P L} / W C_{w a t e r}$ (NAPL side)

$\frac{d C_{\text {water }}}{d t}=K_{\text {water }}^{N A P L} / W a\left(\frac{C_{\text {NAPL }}}{K_{\text {NAPL } / W}}-C_{\text {water }}\right)($ Water side $)$ 
Where $C_{\text {NAPL }}$ and $C_{\text {water }}$ are the VOC concentrations in the NAPL and in water respectively, $K_{N A P L}^{N A P L / W}$ and $K_{\text {water }}^{N A P L} / W$ are the global mass transfer coefficients of VOC $\left(\mathrm{m}^{-1} \mathrm{~s}^{-1}\right)$ in the NAPL and in water respectively $\left(\mathrm{mol} . \mathrm{m}^{-3}\right), K_{N A P L} W$ is the specific VOC partition coefficient between the NAPL and water (dimensionless), and $a$ is the volumetric interfacial area $\left(\mathrm{m}^{2} \cdot \mathrm{m}^{-3}\right)$.

Obviously, the global mass transfer coefficient and the volumetric interfacial area should be as high as possible to increase mass transfer in the aqueous phase.

A specific VOC partition coefficient can be defined by the NAPL on water VOC concentration ratio (Eq. 11), and should be as high as possible to obtain the highest concentration gradient. Various coefficients for toluene partition between various NAPL and water are collected in Table 11:

$K_{N A P L / W}=\frac{[V O C]_{N A P L}}{[V O C]_{\text {Water }}}$

Owing to the low aqueous VOC solubility, a maximum VOC concentration in water is rapidly reached, leading to the cessation of VOC mass transfer. However, mass transfer between both liquid phases (NAPL and water) is controlled by the VOC biodegradation in the aqueous phase.

The determination of the VOC concentration in the aqueous phase containing microorganisms is given by the following relation (Eq. 12):

$$
\frac{d C_{\text {Water }}}{d t}=K_{\text {Water }}^{N A P L} a\left(\frac{C_{N A P L}}{K_{N A P L / W}}-C_{W a t e r}\right)-q_{S} x^{\prime}
$$

Where $q_{S}$ is the specific substrate uptake rate and $x^{\prime}$ the biomass concentration.

Several authors showed the importance of the interfacial area in VOC biodegradation in a TPPB (AsconCabrera and Lebeault 1993, 1995; Nakahara et al. 1977; Woodley et al. 1991). Besides, some other parameters such as the stirring speed, the interfacial tension of the NAPL and the NAPL/water ratio in the bioreactor have an impact on the interfacial area. For instance, Ascon-Cabrera and Lebeault (Ascon-Cabrera and Lebeault 1995) showed that the NAPL/water ratio in a TPPB plays a role on the interfacial area when this ratio increases up to $40 \%$. A NAPL on water ratio in the range of $20-30 \%$ was found to be the most efficient for some VOC biodegradation (Darracq et al. 2012). The low biological activity outside this range (less than $20 \%$ or more than $30 \%$ ) can be explained by interfacial area phenomena, since for a small proportion of oil, the emulsion is homogeneous but the interfacial area is small; while for high ratios, the oil is not completely emulsified and hence mass transfer appears limiting leading to a decreasing substrate availability.

\section{Screening and choice of the NAPL}

In view of process optimisation, the intrinsic NAPL properties should also be considered. Indeed, the NAPL should not add pollution, must be non-flammable, and its chemical and thermal properties must fulfil those required with the aim of its recycling (Bruce and Daugulis 1991). The NAPL must be a weakly viscous liquid 
in a range of temperature between 5 and $40^{\circ} \mathrm{C}$. To make the separation from water after biodegradation step feasible, NAPL leading to stable emulsions should be avoided.

The literature concerning NAPL density reports that a high density would increase the pressure drop and hence the operation cost. On the other hand, density should differ from that of water in order to improve the separation step (in the settler).

A lot of significant parameters have to be considered for the choice of an adequate NAPL for the process coupling absorption and biodegradation. However, each system is specific due to the large number of NAPL available and the various microorganisms used.

All the collected NAPL have been previously used either in a two-phase partitioning bioreactor or as absorbents in a gas-liquid contactors (scrubber, airlift, bubble column, etc). Among them, a large number are biodegradable since after an acclimation time, bacteria are able to assimilate these compounds, particularly alkanes, ketones or hydroxylated NAPL (carboxylic acid, aldehydes, etc). NAPL containing long alkyl chains or alcohol, ester or carboxylic groups are also biodegradable, and are precursors of beta oxidation. Other NAPL like phthalates or plasticiser compounds (for example adipates) can also be degraded by various microorganisms such as Rhodococcus or Sphingomonas (Nalli et al. 2006; Liang et al. 2008).

However, various authors showed that biodegradability decreases with the presence of long alkyl chains or hydroxyl, ester and acid groups in the molecule (Muñoz et al. 2006; Déziel et al. 1999). Previously, Alexander (Alexander 1973) reported that a high molecular weight compound, with lot of ramifications, is biologically recalcitrant. Besides, the type, the number, and the position of the substitutes on simple organic molecules influence their biodegradability. For instance, the substitution of a hydrogen atom by chlorine decreases the biodegradability of the molecule. Various compounds having a very low degradation rate or a total refractory towards microorganism are described as bio-recalcitrant. However, recalcitrance is not enough for the proposed process since it means a biodegradation of the considered NAPL after an acclimation time.

According to Ascon-Cabrera and Lebeault (Ascon-Cabrera and Lebeault 1993, 1995) and Déziel et al. (Déziel et al. 1999), four kinds of NAPL are potentially non-biodegradable:

- $\operatorname{HMN}(2,2,4,4,6,8,8$-Heptamethylnonane) owing to the presence of terminal methyl groups. Some authors showed the resistance of HMN to biodegradation by Arthrobacter (Efroymson and Alexander 1991) or mixed cultures (Ghoshal et al. 1996; Kirkwood et al. 2008); while marine microbial community would be able to degrade HMN (Rontani and Giusti 1986).

- Fluorocarbon FC 40 has been tested by Césario et al. (Césario et al. 1998), who could not put its biodegradation in evidence. However, recent reports questioned on the high volatility of this compound and its high power of depletion on ozone (Quijano et al. 2009).

- Polymers are potentially usable in a TPPB. The polyisobutylene is recalcitrant towards microorganisms (Alexander 1973) since constituted of many terminal methyl groups. However, the viscosity of this polymer is high and will increase the pressure drop in the gas/liquid contactor, and/or the stirred power needed in order to create a maximal interfacial area to improve the transfer in the aqueous phase. In this case, the process consumes a large amount of energy. 
- Silicone oil (polymethylsiloxane or PDMS) has been used by several authors (Ascon-Cabrera and Lebeault 1993, 1995; Bouchez et al. 1995; Gardin et al. 1999; Fazaelipoor and Shojaosadati 2002; Aldric et al. 2009a) as an absorbent and a pollutant tank in a multiphase bioreactor. Among the various polymers of this family, all are potentially usable as NAPL in TPPB, owing to their commonly accepted absence of biodegradability. They should be, however, considered with circumspection due to the following general features, a high viscosity and a solid state at ambient temperature.

- The last class of compounds concerns ionic liquids (IL), which are more or less biodegradable, depending on their structure.

Besides NAPL biodegradability, other parameters such as viscosity, toxicity to humans and the environment refine the choice and lead to the elimination of many NAPL.

Finally, all organic solvents such as alkanes, alkynes, carboxylic acids, phtalates, plasticiser compounds... are not usable in TPPB because they are easily metabolized by microorganisms. Among the remaining solvents, HMN is a recalcitrant compounds with terminal methyl groups; however, it is biodegradable after a long contact-time with some bacterial agents, while trihexylamine and fluorocarbons cannot be selected because of their toxicity toward humans or the environment. Among the above solvents, only silicone oils and ionic liquids appear therefore really relevant. Their main characteristics are presented thereafter.

\subsection{Silicone oils}

These oils were synthesized for the first time in 1870. They found an important development due to their physicochemical properties and their physical structure, since they consist of the repetition of a Si-O-Si group. Silicone oils present a good thermal resistance and an excellent chemical inertia facing hydrolysis or oxidation, due to the stability and the strength of the Si-O-Si bonds. Various functional groups can be linked to the silicon atom, leading to several available silicone oils (Fig. 4a) with various viscosities. Finally, the physicochemical properties of these oils are very interesting, for example their superficial tensions are about $20 \mathrm{mN} \cdot \mathrm{m}^{-1}$; it should be remembered that the value for water is $73 \mathrm{mN} . \mathrm{m}^{-1}$. From an environmental point of view, this oil (PDMS) is persistent because it does not bioaccumulate, to adsorb to suspended particle matter (Nendza 2007).

More specifically for hydrophobic VOC removal, among the available silicone oils, polydimethylsiloxane (Fig. 4a) appears as an interesting candidate, since it is biocompatible and non-biodegradable. Some studies reported in Table 12 confirm the relevance of PDMS as a NAPL for the proposed process, namely a tank for hydrophobic or toxic compounds (VOC or PAH) before subsequent biodegradation.

In addition to the high solubility of hydrophobic compounds in PDMS, oxygen is seven times more soluble in silicon oil than in water. In the case of the differentiation of the two steps, absorption and biodegradation, oxygen supply by bubbling is not required in TPPB since a large amount of oxygen present in the oil is available for micro-organisms growth. The kinetics of degradation is not limited by a lack of oxygen.

In this kind of bioreactors, several authors working with silicone oil (Ascon-Cabrera and Lebeault 1993; Osswald P. et al. 1996) noticed a modification of bacterial behaviour due to cell adhesion to the oil leading to a higher interfacial area; the consequence is a more important dispersion of the NAPL and hence an increase of substrate bioavailability. Moreover, using a water/PDMS two-phase system with activated 
sludge, Ascon-Cabrera and Lebeault (Ascon-Cabrera and Lebeault 1993) showed that the microbial activity (growth rate) increases and the lag time decreases compared to a monophasic aqueous system.

Another positive aspect of silicone oil is their biocompatibility for bacterial agents (Darracq et al. 2010c; Darracq et al. 2010a). A large number of bacteria, fungi or microorganisms have the ability to grow in the presence of silicone oil. Enzymes have been also successfully implemented in TPPB containing silicone oil to treat recalcitrant compounds, like anthracene (Eibes et al. 2007); a nearly complete anthracene oxidation was reached using an enzyme peroxidase.

Silicone oil seems therefore the most appropriate NAPL for TPPB.

Concerning the absorption step, PDMS shows interesting physico-chemical properties such as high VOC affinity (Henry's constants) and high mass transfer coefficients. For example, Aldric et al. (Aldric et al. $2009 \mathrm{~b})$ showed that the addition of $10 \%$ PDMS in water increases the mass transfer coefficient of oxygen and isopropylbenzene by $20 \%$. Moreover, these results were confirmed by other authors (Dumont and Delmas 2003; Darracq et al. 2010c). Indeed, the latter authors showed that for a low added amount of PDMS in water, the Henry's constants for hydrophobic VOC decrease rapidly. The relevance of silicon oil for the absorption step is therefore confirmed.

\subsection{Ionic liquids}

These compounds are considered as "green solvents" because they present highly relevant physicochemical properties for environmental applications, especially their low vapour pressure.

Ionic liquids are organic salts consisting of two parts, an organic positive ion like imidazolium (Fig. 4b) and a negative ion, namely the counter-ion, leading to a neutral compound (Table 13) (Yang and Pan 2005). Ionic liquids represent an interesting alternative in various processes (Diels-Alder or Fridel-Crafts reactions, as solvent in liquid-liquid extractions, etc) compared to common organic solvents (methanol, ethanol, etc) (Welton 1999; Docherty and Kulpa 2005). These compounds are also used as media to perform biocatalytic reactions. For instance, Zhang et al. (F. Zhang et al. 2008) used BmimPF6 (1-Butyl-3-methylimidazolium hexafluorophosphate) in a two-phase system (IL/water) to carry out a reduction reaction in the presence of a pure bacterial culture of Aureobasidium pullulans.

Most of the ILs present a low vapour pressure, a low melting point, a high polarity. They are liquid at room temperature, non-flammable, chemically and thermally stable. However, their properties depend on their structure. The effects of positive and negative ions on IL properties are collected in Table 14. Hence, the cation and the anion are selected according to the chemical properties aimed. Therefore, among the various available ionic liquids, 1-butyl-3-methylimidazolium hexafluorophosphate (BmimPF6) and 1-butyl-3methylimidazolium Bis[(trifluoromethyl)sulfonyl]amide seem to be the most relevant for the considered process (Quijano et al. 2011a, 2011b). Unfortunately, the literature dealing with physico-chemical properties linked to absorption, like the Henry's constant values for toluene, or other hydrophobic VOC, as well as their toxicity towards activated sludge and human beings, is scarce.

Although IL toxicity represents a key drawback for their full implementation in bioreactors, their flexible nature is probably the most promising characteristic of these solvents. The possibility to fine-tune practically all the IL physicochemical properties by modifying the alkyl chain or the anion/cation identity 
while conserving key properties such as non-volatility, non-flammability and thermal stability can be considered as an advantage of ILs over traditional solvents (Quijano et al. 2010a).

\section{Conclusion}

The use of a non-aqueous phase liquid (NAPL) can be helpful to remove hydrophobic (or toxic) compound by absorption. Given that organic compounds are more expensive than water commonly employed in absorption processes and can be harmful for environment, its recycling must be envisaged. NAPL reuse can be performed after VOC biodegradation. The choice of the NAPL must therefore fulfill several conditions. Numerous authors have examined such processes, mainly two-phase partitioning bioreactors, namely coupling absorption and biodegradation in the same reactor. A large number of organic solvents have been tested in various experimental conditions, with biodegradation conducted in both pure and mixed cultures; many criteria appear relevant, depending on the target application.

Concerning the absorption step, Henry's constants of VOC in a specific NAPL as well as the NAPL viscosity proved to be key parameters. The VOC solubility in the NAPL should be as high as possible. The viscosity has a negative effect on pressure drop in the gas-liquid contactor and on VOC diffusion, and hence on mass transfer from the gas phase to the NAPL phase. Regarding biodegradation, several parameters must be considered. The non-biodegradability of the selected NAPL is crucial, but its biocompatibility and an absence of toxicity towards microorganisms are also relevant.

Taking into account all these parameters, silicone oils seem to be the most appropriate NAPL for the proposed integrated process. They are non-biodegradable, biocompatible with most of the microorganisms, can be weakly viscous, are efficient absorbents for hydrophobic VOC, have a good partition coefficient for water and promote gas-liquid mass transfer.

Otherwise, even if only few data on their long time behaviour are available, the potentialities of ionic liquids should be more deeply investigated.

All these considerations will be helpful in order to design and optimize a sustainable, performing, cheap and compact process coupling absorption and biodegradation for VOC removal. 


\section{References}

Abe, A., Inoue, A., Usami, R., Moriya, K., \& Horikoshi, K. (1995). Degradation of polyaromatic hydrocarbons by organic solvent-tolerant bacteria from deep sea. Bioscience Biotechnology and Biochemistry, 59, 1154-1156.

Abed, R. M. M., \& Köster, J. (2005). The direct role of aerobic heterotrophic bacteria associated with cyanobacteria in the degradation of oil compounds. International Biodeterioration and Biodegradation, 55, 29-37.

Aldric, J. M., Gillet, S., Delvigne, F., Blecker, C., Lebeau, F., Wathelet, J. P., et al. (2009a). Effect of surfactants and biomass on the gas/liquid mass transfer in an aqueous-silicone oil two-phase partitioning bioreactor using Rhodococcus erythropolis T902.1 to remove VOCs from gaseous effluents. J. Chem. Technol. Biotechnol., 84, 1274-1283.

Aldric, J. M., Lecomte, J. P., \& Thonat, P. (2009b). Study on mass transfer of isopropylbenzene and oxygen in a twophase partitioning bioreactor in the presence of silicone oil. Appl. Biochem. Biotechnol., 153, 67-79.

Aldric, J. M., \& Thonart, P. (2008). Performance of a water/silicone oil two-phase partitioning bioreactor using Rhoococcus erythropolis T902.1 to remove volatile organic compounds from gaseous effluents. J. Chem. Technol. Biotechnol., 83, 1401-1408.

Alexander, M. (1973). Non-biodegradadable and other recalcitrant molecules. Biotechnol. Bioeng., 15, 611-647.

Alvarez, P. J., \& Vogel, T. M. (1991). Substrate interactions of benzene, toluene, and para-xylene during microbial degradation by pure cultures and mixed culture aquifer slurries. Appl. Environ. Microbiol., 57(10), 2981-2985.

Arriaga, S., Muñoz, R., Hernandez, S., Guieysse, B., \& Revah, S. (2006). Gaseous hexane biodegradation by Fusarium solani in two liquid phase packed-bed and stirred tank bioreactors. Environ. Sci. Technol., 40, 2390-2395.

Ascon-Cabrera, M. A., \& Lebeault, J. M. (1993). Selection of xenobiotic-degrading microorganisms in a biphasic aqueous-organic system. Appl. Environ. Microbiol., 59, 1717-1724.

Ascon-Cabrera, M. A., \& Lebeault, J. M., . (1995). Cell hydrophobicity influencing the activity/stability of xenobioticdegrading microorganisms in a continous biphasic aqueous-organic system. J. ferment. Bioeng., 80, 270-275.

Barnabe, E. S., Beauchesne, I., Cooper, D. G., \& Nicell, J. A. (2008). Plasticizers and their degradation products in the process streams of a large urban physicochemical sewage treatment plant. Water Res., 42, 153-162.

Berekaa, M. M., \& Steinbüch, A. (2000). Microbial Degradation of the Multiply Branched Alkane 2,6,10,15,19,23Hexamethyltetracosane (Squalane) by Mycobacterium fortuitum and Mycobacterium ratisbonense. Appl. Environ. Microbiol., 66, 4462-4467.

Biard, P. F., Couvert, A., Renner, C., \& Levasseur, J. P. (2010). Wet scrubbing intensification applied to hydrogen sulphide removal in waste water treatment plant. Can. J. Chem. Eng., 88, 682-687.

Biard, P. F., Couvert, A., Renner, C., Zozor, P., Bassivière, S., \& Levasseur, J. P. (2009). Hydrogen sulphide removal in waste water treatment plant by compact oxidative scrubbing in Aquilair PlusTM process. Water Practice Technol., 4, doi:10.2166/wpt.2009.2023.

Birman, I., \& Alexander, M. (1996). Optimizing biodegradation of phenanthrene dissolved in nonaqueous-phase liquids. Appl. Microbiol. Biotechnol., 45, 267-272.

Bouchez, M., Blanchet, D., \& Vandecasteele, J. P. (1995). Substrate availability in phenanthrene biodegradation by natural microbial communities. Appl. Microbiol. Biotechnol., 43, 952-960.

Bouchez, M., Blanchet, D., \& Vandecasteele, J. P. (1997). An interfacial uptake mechanism for the degradation of pyrene by Rhodococcus strain. Microbiol., 143, 1087-1093.

Boudreau, N. G., \& Daugulis, A. J. (2006). Transient performance of two phase partitioning bioreactor treating a toluene contaminated gas stream. Biotechnol. Bioeng., 94, 448-457.

Bourgois, D., Thomas, D., Fanlo, J. L., \& Vanderschuren, J. (2006). Solubilities at High Dilution of Toluene, Ethylbenzene, 1,2,4-Trimethylbenzene, and Hexane in Di-2-ethylhexyl, Diisoheptyl, and Diisononyl Phthalates. J. Chem. Eng. Data, 51, 1212-1215.

Bourgois, D., Vanderschuren, J., \& Thomas, D. (2009). Study of mass transfer of VOCs into viscous solvents in a pilotscale cables-bundle scrubber. Chem. Eng. J., 145, 446-452.

Brink, L. E. S., Tramper, J., Luyben, K. C. A. M., \& Van 't Riet, K. (1988). Biocatalysis in organic media. Enzyme Microb. Technol., 10, 743-736.

Bruce, L. J., \& Daugulis, A. J. (1991). Solvent selection strategies for extractive biocatalysis. Biotechnol. Prog., 61, 116-124.

Burgess, J. E., Parsons, S. A., \& Stuetz, R. M. (2001). Developments in odour control and waste gas treatment biotechnology: a review Biotechnol. Adv., 19, 35-63.

Cannon, P., St Pierre, L. E., \& Miller, A. A. (1960). Solubilities of hydrogen and oxygen in polydimethylsiloxanes. $J$. Chem. Eng. Data, 5, 236.

Césario, M. T., Baverloo, W. A., Tramper, J., \& Beeftink, H. H. (1997a). Enhancement of gas liquid mass transfer rate of apolar pollutants in the biological waste gas treatment by a dispersed organic solvent. Enzyme Microb. Technol., 21, 578-588. 
Césario, M. T., Brandsma, J. B., Boon, M. A., Tramper, J., \& Beeftink, H. H. (1998). Ethene removal from gas by recycling a water-immiscible solvent through a packed absorber and a bioreactor. J. Biotechnol., 62, 105-118.

Césario, M. T., de Wit, H. L., Tramper, J., \& Beeftink, H. H. (1997b). Dispersed organic solvent to enhance the overall gas/water mass transfer coefficient of apolar compounds in the biological waste-gas treatment. Modeling and evaluation. Biotechnol. Prog., 13, 399-407.

Cha, J. M., Cha, W. S., \& Lee, J. H. (1999). Removal of organo-sulphur odour compounds by Thiobacillus novellus SRM, sulphur-oxidizing microorganisms. Process Biochem., 34, 659-665.

Clarke, K. G., \& Correia, L. D. C. (2008). Oxygen transfer in hydrocarbon-aqueous dispersion and its applicability to alkane bioprocess: A review. Biochem. Eng. J., 39, 405-429.

Collins, L. D., \& Daugulis, A. J. (1997a). Biodegradation of phenol at high initial concentration in two-phase partitioning batch and fed batch bioreactors. Biotechnol. Bioeng., 55, 155-162.

Collins, L. D., \& Daugulis, A. J. (1997b). Characterization and optimization of a two-phase partitioning bioreactor for the biodegradation of phenol. Appl. Microbiol. Biotechnol., 48, 18-22.

Collins, L. D., \& Daugulis, A. J. (1999a). Benzene/Toluene/p-Xylene degradation. Part I: Solvent selection and toluene degradation in a two-phase partitioning bioreactor. Appl. Microbiol. Biotechnol., 52, 354-359.

Collins, L. D., \& Daugulis, A. J. (1999b). Part II. Effect of substrate interactions and feeding strategies in toluene/benzene and toluene/p-xylene fermentations in a partitioning bioreactor. Appl. Microbiol. Biotechnol., $52,360-365$.

Collins, L. D., \& Daugulis, A. J. (1999c). Simultaneous biodegradation of benzene, toluene and p-xylene in a two-phase partitioning bioreactor: concept demonstration and practical application. Biotechnol. Prog., 15, 74-80.

Cui, H., \& Turn, S. Q. (2009). Adsorption/desorption of dimethylsulfide on activated carbon modified with iron chloride. App. Cat. B-Environ., 88, 25-31.

Darracq, G., Couvert, A., Couriol, C., Amrane, A., \& Le Cloirec, P. (2009). Absorption and biodegradation of hydrophobic VOCs: determination of Henry's constants and biodegradation levels. Water Sci. Technol., 59, 1315-1322.

Darracq, G., Couvert, A., Couriol, C., Amrane, A., \& Le Cloirec, P. (2010a). Integrated process for hydrophobic VOC treatment - Solvent choice. Can. J. Chem. Eng., 88(4), 655-660.

Darracq, G., Couvert, A., Couriol, C., Amrane, A., \& Le Cloirec, P. (2010b). Kinetics of toluene and sulfur compounds removal bymeans of an integrated process involving the coupling of absorption and biodegradation. J. Chem. Technol. Biotechnol., 85, 1156-1161.

Darracq, G., Couvert, A., Couriol, C., Amrane, A., Thomas, D., Dumont, E., et al. (2010c). Silicone oil: An effective absorbent for hydrophobic Volatile Organic Compounds (VOC) removal. J. Chem. Technol. Biotechnol., 85, 309-313.

Darracq, G., Couvert, A., Couriol, C., Amrane, A., Thomas, D., Dumont, E., et al. (2012). Optimization of the volume fraction of the NAPL, silicon oil, and biodegradation kinetics of toluene and DMDS in a TPPB. Int. Biodeter. Biodeg., 71, 9-14.

Daugulis, A. J. (2001). Two-phase partitioning bioreactors: a new technology platform for destroying xenobiotics. Trends Biotechnol., 19, 457-462.

Daugulis, A. J., \& Boudreau, N. G. (2003). Removal and destruction of high concentration of gaseous toluene in a twophase partitioning bioreactor by Alcaligenes xylosoxidans. Biotechnol. Lett., 25, 1421-1424.

De Bont, J. A. M. (1998). Solvent-tolerant bacteria in biocatalysis. Trends Biotechnol., 16, 493-498.

De Guardia, A. (1994). Epuration de gaz comportant des composés organo-soufrés. Etude d'un procédé physicochimique. Université de Rennes 1, ENSCR,

Desai, J. D., \& Banat, I. M. (1997). Microbial production of surfactants and their commercial potential. Microbiol. Mol. Biol. Rev., 61, 47-64.

Deshusses, M. A. (1997). Biological waste air treatment in biofilters. Curr. Opin. Biotechnol., 8, 335-339.

Devos, M., Patte, F., Rouault, J., Laffort, P., \& Van Gemert, L. J. (1990). Standardized human olfactory thresholds: Oxford University Press, New York.

Déziel, E., Commeau, Y., \& Villemur, R. (1999). Two-liquid-phase bioreactors for enhanced degradation of hydrophobic/toxic compounds. Biodegradation, 10, 219-233.

Docherty, K. M., Dixon, J. K., \& Kulpar, J. C. F. (2007). Biodegradation of imidazolium and pyridinium ionic liquids by an activated skudge microbial community. Biodegradation, 18, 481-493.

Docherty, K. M., \& Kulpa, C. F. (2005). Toxicity and antimicrobial activity of imidazolium and pyridinium ionic liquids. Green Chem., 7, 185-189.

Dumont, E., Andrès, Y., \& Le Cloirec, P. (2006). Mass transfer coefficients of styrene and oxygen into silicone oil emulsions in a bubble reactor. Chem. Eng. Sci., 61, 5612-5619.

Dumont, E., Darracq, G., Couvert, A., Couriol, C., Amrane, A., Thomas, D., et al. (2010). Determination of partition coefficients of three volatile organic compounds (dimethylsulphide, dimethyldisulphide and toluene) in water/silicone oil mixtures. Chem. Eng. J., 162, 927-934. 
Dumont, E., Darracq, G., Couvert, A., Couriol, C., Amrane, A., Thomas, D., et al. (2011). VOC absorption in a countercurrent packed-bed column using water/silicone oil mixtures: Influence of silicone oil volume fraction. Chem. Eng. J., 168, 241-248.

Dumont, E., \& Delmas, H. (2003). Mass transfer enhancement of gas absorption in oil-in-water systems: a review. Chem. Eng. Process., 42, 419-438.

Eaton, R. W., \& Ribbons, D. W. (1982). Metabolism of Dibutylphthalate and Phthalate by Micrococcus sp. Strain $12 B$. J. Bacteriol., 151, 48-57.

Efroymson, R. A., \& Alexander, M. (1991). Biodegradation by an Arthrobacter species of hydrocarbons partitioned into an organic solvent. App. Environ. Microbiol., 57, 1441-1447.

Eibes, G., Moreira, M. T., Feijo, G., Daugulis, A. J., \& Lema, J. M. (2007). Operation of a two-phase partitioning bioreactor for the oxidation of anthracene by the enzyme manganese peroxidise. Chemosphere, 66, 1744-1751.

Estévez, E., Veiga, M. C., \& Kennes, C. (2005). Biofiltration of waste gases with the fungi Exophilia oligosperma and Paecilomyces variotii. Appl. Microb. Biotechnol., 67, 563-568.

Fall, R. R., Brown, J. L., \& Schaeffer, T. L. (1979). Enzyme recruitment allows the biodegradation of recalcitrant branched hydrocarbons by Pseudomonas citronellis. Appl. Environ. Microbiol., 38(4), 715-722.

Fazaelipoor, M. H., \& Shojaosadati, S. A. (2002). The effect of silicone oil on biofiltration of hydrophobic compounds. Environ. Prog., 21, 221-224.

Fei, W. Y., \& Bart, H. J. (2001). Predicting diffusivities in liquids by the group contribution method. Chem. Eng. Process., 40, 531-335.

Fewson, C. A. Factors affecting the degradation hazardous recalcitrant materials. In R. F. S. o. Engineers (Ed.), Proc. Int. Symp. Environ. Biotechnol., Ostend, 1991 (Vol. 1, pp. 173-183)

Fritsche W., \& Hofrichter M. (2005). Aerobic Degradation by Microorganisms. In R. G. Rehm H.J. (Ed.), Biotechnology set, $2^{\text {nd }}$ Ed - Part XIb: Environmental Processes II - II Microbiological Aspects (pp. 144-167): Wiley.

Gardin, H., Lebeault, J. M., \& Pauss, A. (1999). Biodegradation of xylene and butyl acetate using an aqueous-silicon oil two phase system. Biodegradation, 10, 193-200.

Ghoshal, S., Ramaswami, A., \& Luthy, R. G. (1996). Biodegradation of naphthalene from coal tar and heptamethylnonane in mixed batch system. Environ. Sci. Technol., 30, 1282-1291.

Guieysse, B., Cirne, M. D. D. T. G., \& Mattiasson, B. (2001). Microbial degradation of phenanthrene and pyrene in a two-liquid-phase-partitioning bioreactor. Appl. Microbiol. Biotechnol., 56, 796-802.

Guieysse, B., Hort, C., Platel, V., Munoz, R., Ondarts, M., \& Revah, S. (2008). Biological treatment of indoor air for VOC removal: Potential and challenges. Biotechnol. Adv., 26, 398-410.

Hamed, T. A., Bayraktar, E., Mehmetoglu, U., \& Mehmetoglu, T. (2004). The biodegradation of benzene, toluene and phenol in a two-phase system. Biochem. Eng. J., 19, 137-146.

Hansen, K. C., Zhou, Z., Yaws, C. L., \& Aminabhavi, T. M. (1993). Determination of Henry's law constants of organics in dilute aqueous solutions. J. Chem. Eng. Data., 38, 546-550.

Hartikainen, T., Martikainen, P. J., Olkkonen, M., \& Ruuskanen, J. (2002). Peat biofilter in long-term experiments for removing odorous sulphur compounds. Water Air Soil Pollut., 133, 335-348.

Hayachi, S., Kobayashi, T., \& Honda, H. (2003). Simple and Rapid Cell Growth Assay Using Tetrazolium Violet Coloring Method for Screening of Organic Solvent Tolerant Bacteria. J. Biosc. Bioeng., 96, 360-363.

Heipieper, H. J., Grit, N., Cornelissen, S., \& Meinhrdart, F. (2007). Solvent-tolerant bacteria for biotransformations in two-phase fermentation system. Appl. Microbiol. Biotechnol., 74, 961-973.

Hernández, M., Quijano, G., Muñoz, R., \& Bordel, S. (2011). Modeling of VOC mass transfer in two-liquid phase stirred tank, biotrickling filter and airlift reactors. Chem. Eng. J., 172, 961-969.

Heymes, F. (2005). Traitement d'air chargé en COV hydrophobes par un procédé hybride :Absorption-Pervaporation. Université de Montpellier II,

Heymes, F., Demoustier, P. M., Charbit, F., Fanlo, J. L., \& Moulin, P. (2006). A new efficient absorption liquid to treat exhaust air loaded with toluene. Chem. Eng. J., 115, 225-231.

Heymes, F., Demoustier, P. M., Charbit, F., Fanlo, J. L., \& Moulin, P. (2007). Treatment of gas containing hydrophobic VOCs by a hybrid absorption-pervaportion process: the case of toluene. Chem. Eng. Sci., 62, 2576-2589.

Hine, J., \& Weimar, J. R. D. (1965). Carbon Basicity. J. Am. Chem. Soc., 87, 3387-3396.

Huddleston, J. G., Visser, A. E., Reichert, W. M., Willauer, H. D., Broker, G. A., \& Rogers, R. D. (2001). Characterization and comparaison of hydrophilic and hydrophobic room temperature ionic liquids incorporating the imidazolium cation. Green Chem., 3, 156-164.

Iliuta, M. C., \& Larachi, F. (2005a). Gas Liquid partition coefficients and Henry's law constants of DMS in aqueous solutions of Fe(II) chelate complexes using the static headspace method. J. Chem. Eng. Data, 50, 1700-1705.

Iliuta, M. C., \& Larachi, F. (2005b). Solubility of dimethyldisulfide (DMDS) in aqueous solutions of Fe(III) complexes of trans-1,2-cyclohexanediaminetetraacetic acid (CDTA) using the static headspace method. Fluid phase Equilibria, 233, 184-189.

Inoue, A., \& Horikoshi, K. (1991). Estimation of solvent-tolerance of bacteria by the solvent parameter log P. J. ferment. Bioeng., 71, 194-196. 
Janikowski, T. B., Velicogna, D., Punt, M., \& Daugulis, A. (2002). Use of a two-phase partitioning bioreactor for degrading polycyclic aromatic hydrocarbons by Sphingomonas sp. . J. Appl. Microbiol. Biotechnol., 59, 368376.

Jimenez, I. Y., \& Bartha, R. (1996). Solvent-Augmented Mineralization of Pyrene by a Mycobacterium sp. App. Environ. Microbiol., 62, 2311-2316.

Kennes, C., Rene, E. R., \& Veiga , M. C. (2009). Bioprocess for air pollution control. J. Chem. Technol. Biotechnol., 84, 1419-1436.

Kester, A. S., \& Foster, J. W. (1963). Diterminal oxidation of long chain alkanes by bacteria. J. Bacteriol., 85, 859-869.

Kirkwood, K. M., Chernik, P., Foght, J. M., \& Gray, M. R. (2008). Aerobic biotransformation of decalin (decahydronaphtalene) by Rhodococcus spp. Biodegradation, 19, 785-794.

Koma, D., Hasumi, F., Yamamoto, E., Ohta, T., Chung, S. Y., \& Kumo, M. (2001). Biodegradation of long-chain nparaffins from waste oil of car engine by Acinetobacter sp. J. Biosc. Bioeng., 91, 95-96.

Koma, D., Sakashita, Y., Kubota, K., Fujii, Y., Hasumi, F., Chung, S. Y., et al. (2003). Degradation of Car engine Base oil by Rhodococcus sp. NDKK48 and Gordonia s.p NDKY76A. Biosci. Biotechnol. Biochem., 67, 1590-1593.

Laane, C., Boeren, S., \& Vos, K. (1985). On optimizing organic solvents in multi-liquid-phase biocatalysis. Trends Biotechnol., 3, 251-252.

Laane, C., Boeren, S., Vos, K., \& Veeger, C. (1987). Rules for optimization of biocatalysis in organic solvents. Biotechnol. Bioeng., 30, 81-87.

Le Cloirec, P. (1998). Les composés organiques volatils (COV) dans l'environnement. Paris: Lavoisier TEC\&DOC.

Lee, E. H., \& Cho, K. S. (2008). Characterization of cyclohexane and hexane degradation by Rhodococcus sp. EC1. Chemosphere, 71, 1738-1744.

Liang, D. W., Zhang, T., Fang, H. H. P., \& He, J. (2008). Phtalates biodegradation in the environment. Appl. Microbiol. Biotechnol., 80, 183-198.

Mackay, D., \& Shiu, W. Y. (1981). A critical review of Henry's law constants for chemicals of environmental interest. J. Phys. Chem. Ref. Data, 10, 1175-1199.

Mackay, D., Shiu, W. Y., \& Sutherland, R. P. (1979). Determination of air-water Henry's law constants for hydrophobic pollutants. Environ. Sci. Technol., 13, 333-337.

MacLeod, C. T., \& Daugulis, A. J. (2003). Biodegradation of polycyclic aromatic hydrocarbons in two phase partitioning bioreactor in the presence of a bioavailable solvent. Appl. Microbiol. Biotechnol., 62, 291-296.

MacLeod, C. T., \& Daugulis, A. J. (2005). Interfacial effects in a two-phase partitioning bioreactor: degradation of polycyclic aromatic hydrocarbons (PAHs) by a hydrophobic Mycobacterium. Process Biochem., 40, 17991805.

MacMillan, J. D., \& Wang, D. I. C. (1987). Enhanced oxygen transfer using oil-in-water dispersion. Ann. NY Acad. Sci., 506, 569-582.

Mahanty, B., Pakshirajan, K., \& Venkata Dasu, V. (2010). A two liquid phase partitioning bioreactor system for the biodegradation of pyrene: Comparative evaluation and cost-benefit analysis. J. Chem. Technol. Biotechnol., 85(3), 349-355.

Mahanty, B., Parkshirajan, K., \& Dasu, V. V. (2008). Biodegradation of pyrene by Mycobacterium frederiksbergense in a two-phase partitioning bioreactor system. Bioresour. Technol., 99, 2694-2698.

Malinowski, J. J. (2001). Two-phase partitioning bioreactors in fermentation technology. Biotechnol. Adv., 19, $525-538$.

Marcoux, J., Déziel, E., Villemur, R., Lépine, F., Bisaillon, J. G., \& Beaudet, R. (2000). Optimization of high molecular weight polycyclic aromatic hydrocarbons' degradation in a two-liquid-phase bioreactor. J. Appl. Microbiol., $88,655-662$.

Matsumoto, M., Mochiduki, K., \& Kondo, K. (2004). Toxicity of Ionic Liquids and Organic Solvents to Lactic AcidProducing Bacteria. J. Biosci. Bioeng., 98, 344-347.

Miller, J. M., \& Allen, D. G. (2004). Transport of hydrophobic pollutants throught biofilms in biofilters. Chem. Eng. Sci., 59, 3515-3525.

Mohseni, M., \& Allen, D. G. (2000). Biofiltration of hydrophilic and hydrophobic volatile organic compounds. Chem. Eng. Sci., 55, 1545-1558.

Montes, M., C. Veiga, M. C., \& Kennes, C. (2011). Effect of oil concentration and residence time on the biodegradation of $\alpha$-pinene vapours in two-liquid phase suspended-growth bioreactors. J. Biotechnol., doi:10.1016/j.jbiotec.2011.1007.1019.

Muñoz, R., Arriaga, S., Hernandez, S., Guieysse, B., \& Revah, S. (2006). Enhanced hexane biodegradation in a two phase partitioning bioreactor: overcoming pollutant transport limitations. Process Biochem., 41, 1614-1619.

Muñoz, R., Villaverde, S., Guieysse, B., \& Revah, S., T , (2007). Two-phase partitioning bioreactor for treatment of volatile organic compounds. Biotechnol. Adv., 25, 410-422.

Nakahara, T., Erickson, L. E., \& Gutierrez, J. R. (1977). Characteristics of hydrocarbons uptake in cultures with two liquid phases. Biotechnol. Bioeng., 19, 9-25.

Nalli, S., Cooper, D. G., \& Nicell, J. A. (2006). Metabolites from the biodegradation of di-ester plasticizers by Rhodococcus rhodochrous. Sci. Total Environ., 366, 286-294. 
Nendza, M. (2007). Hazard assessment of silicone oils (polydimethylsiloxanes, PDMS) used in antifouling-/foulrelease-products in the marine environment. Mar. Pollut. Bull., 54, 1190-1196.

Nhi-Cong, L. T., Mikolash, A., Klenk, H. P., \& Schauer, F. (2009). Degradation of the multiple branched alkane 2,6,10,14-tetramethyl-pentadecane (pristine in Rhodococcus ruber and Mycobacterium neoaurum). Int. Biodeter. Biodegr., 63, 201-207.

Nielsen, D. R., Daugulis, A. J., \& Mclellan, P. J. (2005). Transient performance of a two-phase partitioning bioscrubber treating a benzene-contamination gas stream. Environ. Sci. Technol., 39, 8971-8977.

Ogino, H., Miyamoto, K., Yasuda, M., Ishimi, K., \& Ishikawa, H. (1999). Growth of organic solvent-tolerant Pseudomonas aeruginosa LST-03 in the presence of various organic solvents and production of lipolytic enzyme in the presence of cyclohexane. Biochem. Eng. J., 4, 1-6.

Oliveira, F. J. S., \& De França, F. P. (2005). Increase in removal of polycyclic aromatic hydrocarbons during bioremediation of crude oil-contaminated sandy soil. Appl. Biochem. Biotechnol., 121-124, 593-603.

Osborne, S. J., Leaver, J., Turner, M. K., \& Dunill, P. (1990). Correlation of biocatalytic activity in an organic-aqueous two-liquid phase system with solvent concentration in the cell membrane. Enzyme Microb. Technol., 12, 281291.

Osswald P., Baveye, P., \& Block, J. C. (1996). Bacterial influence on partitioning rate during the biodegradation of styrene in a biphasic aqueous-organic system. Biodegradation, 7, 297-302.

Ottengraf, S. P. P., Meesters, J. J. P., Van den Oever, A. H. C., \& Rozema, H. R. (1986). Biological of volatile xenobiotics compounds in biofilters. Bioproc. Biosyst. Eng., 1, 61-69.

Pernafeta-Boldù, F. X., Illa, J., Van Groenestijn, J. W., \& Flotats, X. (2008). Influence of the synthetic packing materials on the gas dispersion and biodegradation kinetics in fungal air biofilters. Appl. Microbiol. Biotechnol., 79, 319-327.

Poddar, T. K., Majumdar, S., \& Sirkar, K. K. (1996). Removal VOCs from air by membrane based absorption and stripping. J. Membr. Sci., 120, 221-237.

Poddar, T. K., \& Sirkar, K. K. (1996). Henry's constant for selected volatile organic compounds in high-boiling oils. J. Chem. Eng. Data, 41, 1329-1332.

Quijano, G., Couvert, A., \& Amrane, A. (2010a). Ionic liquids : Applications and future trends in bioreactor technology. Bioresour. Technol., 101, 8923-8930.

Quijano, G., Couvert, A., Amrane, A., Darracq, G., Couriol, C., Le Cloirec, P., et al. (2011a). Potential of ionic liquids for VOC absorption and biodegradation in multiphase systems. Chem. Eng. Sci., 66, 2707-2712.

Quijano, G., Couvert, A., Amrane, A., Darracq, G., Couriol, C., Le Cloirec, P., et al. (2011b). Toxicity and biodegradability of ionic liquids: New perspectives towards whole-cell biotechnological applications. Chem. Eng. J., 174, 27-32.

Quijano, G., Hernandez, M., Thalasso, F., Muñoz, R., \& Villaverde, S. (2009). Two-phase partitioning bioreactor in environment biotechnology. Appl. Microbiol. Technol., 84, 829-846.

Quijano, G., Rocha-Ríos, J., Hernández, M., Villaverde, S., Revah, S., Muñoz, R., et al. (2010b). Determining the effect of solid and liquid vectors on the gaseous interfacial area and oxygen transfer rates in two-phase partitioning bioreactors. J. Hazard. Mater., 175, 1085-1089.

Rehmann, L., \& Daugulis, A. J. (2007). Biodegradation of biphenyl in a solid-liquid two-phase partitioning bioreactor. Biochem. Eng. J., 36, 195-201.

Revah, S., \& Morgan-Sagastume, J. M. (2005). .Methods of Odor and VOC Control. In S. A. Shareefdeen Z. (Ed.), Biotechnology for Odour and Air Pollution Control (pp. 29-63). Berlin Springer-Verlag, Berlin Heidelberg.

Robbins, G. A., Wang, S., \& Stuart, J. D. (1993). Using the static headspace method to determine Henry's law constant. Anal. Chem., 65, 3113-3118.

Rodriguez, M., Klason, T. K., \& Davison, B. H. (2001). Enhancement of the conversion of toluene by Pseudomonas putida F-1 using organic cosolvents. Appl. Biochem. Biotechnol., 92-93, 195-204.

Rols, J. L., Condoret, J. S., Fonade, C., \& Goma, G. (1990). Mechanisms of enhanced oxygen transfer in fermentation using emulsified oxygen-vectors. Biotechnol. Bioeng., 35, 427-435.

Rontani J.F., Mouzdahir, A., Michotey, V., \& Bonin, P. C. (2002). Aerobic and anaerobic metabolism of squalene by a denitrifying bacterium isolated from marine sediment. Arch. Microbiol., 178, 279-287.

Rontani, J. F., Bonin, P. C., \& Volkman, J. K. (1999). Biodegradation of Free Phytol by Bacterial Communities Isolated from Marine Sediments under Aerobic and Denitrifying Conditions. Appl. Environ. Microbiol., 65, 54845492.

Rontani, J. F., \& Giusti, G. (1986). Study of the biodegradation of poly-branched alkanes by a marine bacterial community. Mar. Chem., 20, 197-205.

Roustan., M. (2003). Transfert gaz-liquide dans les procédés de traitement des eaux et des effluents gazeux. Paris: Lavoisier TEC\&DOC.

Sáez-Navarrete, C., Gelmi, C. A., Reyes-Bozo, L., \& Godoy-Faúndez, A. (2008). An exploratory study of peat and sawdust as enhancers in the (bio)degradation on n-dodecane. Biodegradation, 19, 527-534.

Sardessai, Y., \& Bhosle, S. (2002). Tolerance of bacteria to organic solvents. Res. Microbiol., 153, $263-268$.

Scheibel, E. G. (1954). Liquid diffusivities and viscosity of gases. Ind. Eng. Chem., 46, 2007-2008. 
Seubert, W. (1960). Degradation of isoprenpoid compounds by microorganisms. I. Isolation and characterization of an isoprenoid-degrading bacterium, Pseudomonas citronellolis n. sp. J. Bacteriol., 79, 426-434.

Shu, C. H., \& Chen, C. K. (2009). Enhanced removal of dimethyl sulphide from a waste gas stream using a bioreactor inoculated with Micobacterium sp. NTUT26 and Pseudomonas putida. J. Ind. Mcrobiol. Biotechnol., 36, $95-$ 104.

Sikkema, J., de Bont, J. A., \& Poolman, B. (1995). Mechanisms of membrane toxicity of hydrocarbons. Microbiol. Rev., 59, 201-222.

Singh, A., Shareefdeen, Z., \& Ward, O. P. (2005). Biotechnology for Odour and Air pollution control. In Bioscrubber Technology. Berlin Springer-Verlag, Berlin Heidelerg.

Singh, D., \& Fulekar, M. H. (2010). Benzene bioremediation using cow dung microflora in two phase partitioning bioreactor. J. Hazard. Mater., 175, 336-343.

Singh, L., Ram, M. S., Agarwal, M. K., \& Alam, S. I. (2000). Characterization of Aeromonas hydrophila strains and their evaluation for biodegradation of night soil. J. Microbiol. Biotechnol., 16, 625-630.

Solano-Serena, F., Marchal, R., Heiss, S., \& Vandecasteele, J. P. (2004). Degradation of isooctane by Mycobacterium austroafricanum IFP 2173: growth and catabolic pathway. J. Appl. Microbiol., 97, 629-639.

Staudinger, J., \& Roberts, P. V. (2000). A critical compilation of Henry's law constant temperature dependence relations for organic compounds in dilute aqueous solutions. Chemosphere, 44, 561-576.

Tomei, M. C., Annesini, R. S., \& Daugulis, A. J. (2008). Biodegradation of 4-nitrophenol in a two-phase sequencing batch reactor : concept demonstration, kinetics and modelling. Appl. Microbiol. Biotechnol., 80, 1105-1112.

Trinci, A. P. J. (1969). A kinetic study of the growth of Aspergillus nidulans and other fungi. J. Gen. Microbiol., 57, 1124.

Tudose, R. Z., \& Apreotesei, G. (2001). Mass transfer coefficients in liquid-liquid extraction. Chem. Eng. Process., 40, 447-485.

Van der Meer, J. R., de Vos, W. M., Harayama, S., \& Zehnder, A. J. B. (1992). Molecular mechanisms of genetic adaptation to xenobiotic compounds. Microbiol. Rev., 56, 677-694.

Van der Werf, M. J., Swarts, H. J., \& de Bont, J. A. M. (1999). Rhodococcus erythropolis DCL14 contains a novel degradation pathway for limonene. Appl. Environ. Microbiol., 65, 2092-2102.

Vannek, P., Beekman, M., de Saeyer, N., D'Haene, S., \& Verstraete, W. (1995). Biodegradation of polycyclic aromatic hydrocarbons in a two-liquid phase system. In R. R. Hinchee, D. B. Anderson, \& R. E. Hoeppel (Eds.), Bioremediation of Recalcitrant Organics (Vol. 7, pp. 55-62): Batelle Press.

Vieira, P. A., Vieira, R. B., de Franc, F. P., \& Cardoso, V. L. (2007). Biodegradation of effluent contaminated with diesel fuel and gasoline. J. Hazard. Mater., 140, 52-59.

Vrionis, H. A., Kropinski, A. M., \& Daugulis, A. J. (2002). Enhancement of a Two-Phase Partitioning bioreactor system by modification of the microbial catalyst: Demonstration of concept. Biotechnol. Bioeng., 79, 587-594.

Vuong, M. D., Couvert, A., Couriol, C., Amrane, A., Le Cloirec, P., \& Renner, C. (2009). Determination of the Henry's constant and the mass transfer rate of VOCs in solvents. Chem. Eng. J., 150, 426-443.

Welton, T. (1999). Room-Temperature Ionic liquids. Solvents for synthesis and catalysis. Chem. Rev., 99, 2071-2084.

Wilke, C. R., \& Chang, P. (1955). Correlation of diffusion coefficients in dilute solutions. AIChE J., 1, $264-270$.

Woodley, J. M., Brazier, A. J., \& Lilly, M. G. (1991). Lewis cell studies to determine reactor design data for two-liquidphase bacterial and enzymatic reactions. Biotechnol. Bioeng., 37, 133-140.

Xia, B., Majumbar, S., \& Sirkar, K. K. (1999). Regenerative oil scrubbing of volatile organic compounds from a gas stream in hollow fibber membrane devices. Ind. Eng. Chem. Res., 38, 3462-3472.

Yang, Z., \& Pan, W. (2005). Ionic liquids: Green solvents for non aqueous biocatalysis. Enzyme Microb. Technol., 37, $19-28$.

Yeom, S. H., \& Daugulis, A. J. (2000). Treatment of high concentration gaseous benzene stream using a novel bioreactor system. Biotechnol. Lett., 22, 1747-1751.

Yeom, S. H., \& Daugulis, A. J. (2001a). Development of a novel bioreactor system for treatment of gaseous benzene. Biotechnol. Bioeng., 72, 156-165.

Yeom, S. H., \& Daugulis, A. J. (2001b). A two-phase partitioning bioreactor system for treating benzene-contaminated soil. Biotechnol. Lett., 23, 467-473.

Zhang, F., Ni, Y., Sun, Z., Zheng, P., Lin, W., Zhu, P., et al. (2008). Asymmetric Reduction of Ethyl 4-Chloro-3oxobutanoate to Ethyl(S)-4-Chloro-3-hydroxybutanoate catalyzed by Aureobasidium pullulans in an aqueous/Ionic liquid biphase System. Chin. J. Catal., 29, 577-582.

Zhang, Y., Liss, S. N., \& Allen, D. G. (2007). Enhancing and modelling the biofiltration of dimethyl sulphide under dynamic methanol addition. Chem. Eng. Sci., 62, 2474-2781.

Zhao, D., Liao, Y., \& Zhang, Z. (2007). Toxicity of ionic liquids. Clean, 35, 42-48. 


\section{Figure captions}

Figure 1. Procedure for the choice of the process to be implemented for loaded VOC air treatment (Smeets, 2002)

Figure 2. Hybrid absorption-biodegradation process with regeneration of the organic phase

Figure 3. Mass transfer phenomena in a two-phase partitioning bioreactor

Figure 4. Structure of silicone oils (a), polydimethylsiloxane (PDMS) and polymethylphenylsiloxane (PMPS), as well as that of ionic liquids (b) with various

Table 1. Physical and chemical properties of toluene, DMS and DMDS (Cui and Turn 2009; Staudinger and Roberts 2000; Muñoz et al. 2007)

\begin{tabular}{|c|c|c|c|}
\hline Compounds & Toluene & DMS & DMDS \\
\hline CAS number & $108-88-3$ & $75-18-3$ & $624-92-0$ \\
\hline \multicolumn{4}{|l|}{ Formula } \\
\hline & $\mathrm{C}_{6} \mathrm{H}_{5}-\mathrm{CH}_{3}$ & $\left(\mathrm{CH}_{3}\right)_{2} \mathrm{~S}$ & $\left(\mathrm{CH}_{3}\right)_{2} \mathrm{~S}_{2}$ \\
\hline Molar weight (g.mol ${ }^{-1}$ ) & 92.1 & 62.1 & 94.2 \\
\hline Density & 0.867 & 0.840 & 1.063 \\
\hline Boiling point $\left({ }^{\circ} \mathrm{C}\right)$ & 110.6 & 37.3 & 109.8 \\
\hline Vapour pressure (atm) & $0.029\left(20^{\circ} \mathrm{C}\right)$ & $0.660\left(25^{\circ} \mathrm{C}\right)$ & $0.038\left(25^{\circ} \mathrm{C}\right)$ \\
\hline $\begin{array}{c}\text { Partition coefficient } \\
\text { octanol/water : } \log \mathrm{K}_{\mathrm{ow}}\end{array}$ & 2.6 & 0.9 & 1.8 \\
\hline Solubility in water(mg. $\left.\mathrm{L}^{-1}\right)$ & $526\left(25^{\circ} \mathrm{C}\right)$ & $20.5\left(20^{\circ} \mathrm{C}\right)$ & $2.5\left(20^{\circ} \mathrm{C}\right)$ \\
\hline $\begin{array}{l}\text { Henry's constant in water } \\
\left(\text { atm. } \mathrm{m}^{3} \cdot \mathrm{mol}^{-1}\right)\end{array}$ & $6.410^{-3}\left(25^{\circ} \mathrm{C}\right)$ & $1.6110^{-3}\left(25^{\circ} \mathrm{C}\right)$ & $1.2110^{-3}\left(20^{\circ} \mathrm{C}\right)$ \\
\hline 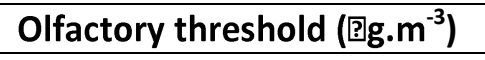 & 8200 & 1.50 & 0.10 (8 to $10 \mathrm{ppb})$ \\
\hline Odour & Plastic $^{a}$ & $\begin{array}{c}\text { Vegetable in } \\
\text { decomposition }\end{array}$ & Putrid \\
\hline
\end{tabular}


Table 2. Examples of multiphase bioreactor systems

\begin{tabular}{|c|c|c|c|c|}
\hline Family compounds & $\begin{array}{c}\text { Xenobiotic or } \\
\text { hydrophobic substrate }\end{array}$ & Microorganisms & Non-aqueous phase liquid & References \\
\hline \multicolumn{5}{|l|}{ Hydrocarbons } \\
\hline \multirow[t]{5}{*}{ BTEX } & Toluene & $\begin{array}{l}\text { Pseudomonas sp., Alcaligenes } \\
\text { xylosoxidans, mixed culture }\end{array}$ & Oleyl alcohol, hexadecane, DEHA* & $\begin{array}{l}\text { (Collins and Daugulis } \\
\text { 1999a, 1999b, 1999c; } \\
\text { Daugulis and Boudreau } \\
\text { 2003: Darraca et al. 2009) }\end{array}$ \\
\hline & Benzene & Kledsiella sp. & Octadecene & (Yeom and Daugulis 2001b) \\
\hline & & Achromobacter xylosoxidans & Hexadecane & (Nielsen et al. 2005) \\
\hline & & Pseudomonas putida & n-Hexadecane & (D. Singh and Fulekar 2010) \\
\hline & Xylene & Pseudomonas sp. & Oleyl alcohol & $\begin{array}{c}\text { (Collins and Daugulis } \\
\text { 1999b) }\end{array}$ \\
\hline \multirow[t]{9}{*}{$\mathrm{PAH}^{*}$} & Pyrene & Mycobacterium frederiksbergense & Silicone oil & (Mahanty et al. 2008; \\
\hline & Various PAHs & Mycobacterium & Bis(ethylhexyl)sebacate & Mahanty et al. 2010) \\
\hline & & Sphingomonas sp. & Dodecane & (MacLeod and Daugulis \\
\hline & Naphtalene, & Pseudomonas sp., Bacillus & Decane, Octadecane, hexane & 2005) \\
\hline & Phenanthrene & Pseudomonas sp. & Silicon oil, HMN & (Janikowski et al. 2002) \\
\hline & & Mixed culture & Hexadecane, dibutylphtalate & (Abe et al. 1995) \\
\hline & Various PAHs & Bacteria consortium & Silicone oil, Paraffin oil, HMN* & (Bouchez et al. 1995) \\
\hline & & & & $\begin{array}{c}\text { (Birman and Alexander } \\
\text { 1996) }\end{array}$ \\
\hline & & & & $\begin{array}{l}\text { (Marcoux et al. 2000; } \\
\text { Vannek et al. 1995) }\end{array}$ \\
\hline \multirow[t]{4}{*}{ Alkanes, Alkenes } & Hexane, & Pseudomonas aeruginosa & Silicone oil & (Muñoz et al. 2006) \\
\hline & Styrene, & Mixed culture & Silicone oil & (Osswald P. et al. 1996) \\
\hline & Ethene & Micobacterium parafortuitum & Fluorocarbon 40 & (Césario et al. 1998) \\
\hline & $\alpha$-pinene & Mixed culture & Silicone oil & (Montes et al. 2011) \\
\hline Sulphur compounds & DMS, DMDS & Mixed culture & DEHA & $\begin{array}{l}\text { (Darracq et al. 2009, } \\
2010 b)\end{array}$ \\
\hline \multirow[t]{3}{*}{$\begin{array}{l}\text { Chlorinated } \\
\text { compounds }\end{array}$} & $\begin{array}{l}\text { 2,4,6-trichlorophenol } \\
\text { 1,2-dichlorobenzene }\end{array}$ & $\begin{array}{l}\text { Pseudomonas } s p . \\
\text { Mixed culture }\end{array}$ & Silicone oil & $\begin{array}{l}\text { (Ascon-Cabrera and } \\
\text { Lebeault 1995) }\end{array}$ \\
\hline & 1,2,3-trichlorobenzene & Mixed culture & Silicone oil & \\
\hline & 1,2,4-trichlorobenzene & Mixed culture & & (Ascon-Cabrera and \\
\hline
\end{tabular}


Lebeault 1993

Other molecules

Phenol

Pseudomonas putida

Rhodococcus spp.

Mixed culture

2-undecanone

HMN

(Collins and Daugulis

1997a, 1997b)

4-nitrophenol

Undecanol, 2-undecanone, oleyl alcohool

(Kirkwood et al. 2008)

(Tomei et al. 2008)

Ethyl butyrate, 2-

Ethylbutyraldehyde,

Mixed culture

Silicone oil

(Ascon-Cabrera and

Butyraldehyde

Lebeault 1993)

DEHA: Di(2-EthylHexyl)Adipate, PAH: Polycyclic Aromatic Hydrocarbons, HMN: HeptaMethylNonane, DMS: DiMethylSulphide, DMDS: diMethylDiSulphide 
Table 3. Comparison between different biological treatments and the alternative process (Mohseni and Allen 2000; Burgess et al. 2001; Miller and Allen 2004; A. Singh et al. 2005; Muñoz et al. 2007; Deshusses 1997; Kennes et al. 2009)

\begin{tabular}{|c|c|c|c|c|}
\hline Characteristics & Biofilter & Biotrickling filter & Bioscrubber & $\begin{array}{c}\text { The Considered process } \\
\text { Absorber + TPPB }\end{array}$ \\
\hline Design & One reactor (open) & One reactor (closed) & Two reactors & Two reactors \\
\hline Liquid absorbent & Water & Water & Water & NAPL \\
\hline Solid phase for absorption & Natural filter bed or inert & $\begin{array}{l}\text { Exclusively inert packing } \\
\text { materials }\end{array}$ & Inert packing materials & Inert packing materials \\
\hline Composition of liquid & $\begin{array}{l}\text { Water with microorganisms } \\
\text { and nutriments }\end{array}$ & Water & Water & $\begin{array}{c}\text { Organic Solvent } \\
\text { or emulsion water/NAPL }\end{array}$ \\
\hline Surface area & High & Low & Low & Low \\
\hline $\begin{array}{c}\text { Concentration of pollutants } \\
\text { and } \\
\text { example }\end{array}$ & $\begin{array}{l}\quad<1 \mathrm{~g} \cdot \mathrm{m}^{-3} \\
\text { Toluene, DMS, Styrene, } \\
\text { 国-pinene, } \mathrm{H}_{2} \mathrm{~S} \text {, Methanol }\end{array}$ & $\begin{array}{c}<0.5 \mathrm{~g} \cdot \mathrm{m}^{-3} \\
\text { Ethanol, Ammonia, DMS, } \\
\mathrm{H}_{2} \mathrm{~S} \text {, Phenol, } \\
\text { Trichloroethylene }\end{array}$ & $\begin{array}{c}<5 \mathrm{~g} \cdot \mathrm{m}^{-3} \\
\mathrm{H}_{2} \mathrm{~S}, \mathrm{SO}_{2}, \text { Alcohols, } \\
\text { aldehydes, Amines, Odours }\end{array}$ & $\begin{array}{c}<0.1 \mathrm{~g} \cdot \mathrm{m}^{-3} \\
\text { Hexane, Toluene, } \\
\text { Dichloromethane, styrene }\end{array}$ \\
\hline 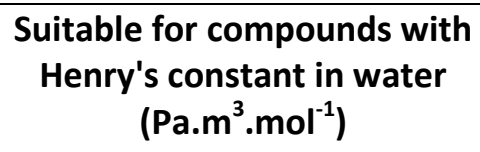 & $<1$ & $<0.1$ & $<0.01$ & $>1$ in water \\
\hline Biomass & Fixed & Fixed & Suspension & Suspension \\
\hline Clogging of packing & Problem & Problem & No problem & No problem \\
\hline Advantages & $\begin{array}{l}\text { Suitable for hydrophobic and } \\
\text { poorly water compounds } \\
\text { removal } \\
\text { Microorganisms naturally } \\
\text { present in the medium } \\
\text { Various types of } \\
\text { microorganisms (bacteria, } \\
\text { fungi, etc) }\end{array}$ & $\begin{array}{l}\text { An easy control of the } \\
\text { operating conditions owing } \\
\text { to the presence of a mobile } \\
\text { liquid phase } \\
\text { Inert packing materials } \\
\text { allows to increase the } \\
\text { gas/liquid transfer }\end{array}$ & $\begin{array}{l}\text { Two-step process, packed } \\
\text { column and bioreactor, } \\
\text { recalcitrant pollutants } \\
\text { removed in the bioreactor } \\
\text { An easy control of the } \\
\text { operating conditions owing } \\
\text { to the presence of a mobile } \\
\text { liquid phase } \\
\text { Activated sludge units } \\
\text { commonly used }\end{array}$ & $\begin{array}{l}\text { Removal of poorly water } \\
\text { soluble compounds and } \\
\text { hydrophobic pollutants } \\
\text { High pollutant } \\
\text { concentrations in NAPL, so } \\
\text { microorganisms are not } \\
\text { exposed to high } \\
\text { concentrations in water } \\
\text { High L/G ratio but NAPL is } \\
\text { regenerated } \\
\text { Enhanced absorber } \\
\text { performances with NAPL as }\end{array}$ \\
\hline
\end{tabular}


absorbent

High interfacial area in

bioreactor by surfactant addition

Medium acidification

Media degradation, high built-up area, high pressure drop increase and low removal efficiency

Compulsory humidification of the gas effluent

Drawbacks

Biodegradation increases medium temperature

Specific inoculums required to treat recalcitrant compounds

Absorption/desorption cycles

Operating conditions $\mathrm{pH}$,

Humidity, water activity, temperature, etc)
High L/G ratio, so operation cost increase and biofilm detachment

Higher residence time in reactor for recalcitrant compounds than for readily biodegradable pollutants

Biomass accumulation leading to pressure drop increase

Non-homogenous biomass distribution
Low residence time in packed column which does not allow hydrophobic VOC absorption

Biomass accumulation, so increase of pressure drop but the high liquid flow rates minimise growth in the scrubber
Pollutants degraded in the aqueous phase

Difficult to find a NAPL non biodegradable and easy to regenerate

Viscous NAPL increase the pressure drop in the absorber

High stirring energy for aeration and agitation 
Table 4. Henry's constants of hydrophobic VOC in water

\begin{tabular}{|c|c|c|c|}
\hline VOC & $\mathrm{H}\left(\mathrm{Pa} \cdot \mathrm{m}^{3} \cdot \mathrm{mol}^{-1}\right)$ & $\mathrm{T}(\mathrm{K})$ & References \\
\hline \multirow{7}{*}{ Toluene } & 675 & 298 & (Mackay et al. 1979) \\
\hline & 670 & 298 & (Mackay and Shiu 1981) \\
\hline & 652 & 298 & (Robbins et al. 1993) \\
\hline & 615 & 298 & (Dumont et al. 2010) \\
\hline & 722 & 301 & (Hansen et al. 1993) \\
\hline & 515 & 295 & (Césario et al. 1997b) \\
\hline & 509 & 293 & (Staudinger and Roberts 2000) \\
\hline \multirow{5}{*}{ Dimethylsulphide } & 124 & 298 & (Dumont et al. 2010) \\
\hline & 180 & 293 & (Hine and Weimar 1965) \\
\hline & 155 & 293 & (Staudinger and Roberts 2000) \\
\hline & 118 & 288 & (Iliuta and Larachi 2005a) \\
\hline & 124 & 298 & (Darracq et al. 2010c) \\
\hline \multirow{5}{*}{ Dimethyldisulphide } & 122 & 298 & (Dumont et al. 2010) \\
\hline & 111 & 293 & (Hine and Weimar 1965) \\
\hline & 77 & 293 & (Staudinger and Roberts 2000) \\
\hline & 112 & 298 & (Iliuta and Larachi 2005b) \\
\hline & 119 & 298 & (Darracq et al. 2010c) \\
\hline \multirow{4}{*}{ Benzene } & 562 & 298 & (Mackay et al. 1979) \\
\hline & 535 & 298 & (Robbins et al. 1993) \\
\hline & 649 & 302 & (Hansen et al. 1993) \\
\hline & 466 & 293 & (Staudinger and Roberts 2000) \\
\hline \multirow[t]{3}{*}{ p-Xylene } & 710 & 298 & (Mackay and Shiu 1981) \\
\hline & 856 & 300 & (Hansen et al. 1993) \\
\hline & 604 & 293 & (Staudinger and Roberts 2000) \\
\hline \multirow[t]{2}{*}{ o-Xylene } & 500 & 298 & (Mackay and Shiu 1981) \\
\hline & 390 & 293 & (Staudinger and Roberts 2000) \\
\hline \multirow[t]{2}{*}{ m-Xylene } & 700 & 298 & (Mackay and Shiu 1981) \\
\hline & 561 & 293 & (Staudinger and Roberts 2000) \\
\hline \multirow{2}{*}{ Ethylbenzene } & 854 & 298 & (Mackay et al. 1979) \\
\hline & 583 & 293 & (Staudinger and Roberts 2000) \\
\hline
\end{tabular}


Table 5. Henry's constants of hydrophobic VOC (Toluene, DMS and DMDS) in organic NAPL $\left(\mathrm{Pa} \cdot \mathrm{m}^{3} \cdot \mathrm{mol}^{-1}\right.$ ) or water/NAPL emulsions

NAPL (viscosity)

DEHA (12.5 mPa.s)

DIB* Phtalate (37.8 mPa.s)

DIH* Phtalate (55.0 mPa.s)

DID* Phtalate (118.8 mPa.s)

DEH Phtalate

Silicone oil (3 mPa.s)

Silicone oil (5 mPa.s)

Silicone oil (20 mPa.s)

Silicone oil (50 mPa.s)

Silicone oil (50 mPa.s)

Silicone oil (500 mPa.s)

PEG 300

PEG 400

PEG 400

Paratherm oil (30 mPa.s)

n-Hexadecane

Oleyl alcoho

Perfluorocarbon FC40

FC40/water

$1 \% \mathrm{v} / \mathrm{v}$ FC40

$3 \% \mathrm{v} / \mathrm{v}$ FC40

$5 \% \mathrm{v} / \mathrm{v}$ FC40

$10 \% \mathrm{v} / \mathrm{v} \mathrm{FC} 40$

*Di-2-EthylHexylPhthalate (DEHP), Di-Iso-HeptylPhthalate (DIHP) and Di-Iso-NonylPhthalate (DINP)

$417\left(22^{\circ} \mathrm{C}\right.$ ) (Césario et al. $\left.1997 \mathrm{a}\right)$ VOC

\begin{tabular}{|c|c|c|}
\hline Toluene & DMS & DMDS \\
\hline $\begin{array}{c}0.9\left(25^{\circ} \mathrm{C}\right) \text { (Vuong et al. 2009) } \\
0.7\left(25^{\circ} \mathrm{C}\right) \text { (F. Heymes 2005) }\end{array}$ & $19.5\left(25^{\circ} \mathrm{C}\right)$ (Vuong et al. 2009) & $1.1\left(25^{\circ} \mathrm{C}\right)$ (Vuong et al. 2009) \\
\hline $\begin{array}{c}\left.0.9\left(25^{\circ} \mathrm{C}\right) \text { (F. Heymes } 2005\right) \\
1.0\left(25^{\circ} \mathrm{C}\right)(\text { F. Heymes } 2005) \\
1.1\left(25^{\circ} \mathrm{C}\right)(\text { F. Heymes } 2005) \\
0.2\left(18^{\circ} \mathrm{C}\right) \text { (Bourgois et al. 2006) }\end{array}$ & - & - \\
\hline $\begin{array}{c}\left.2.3\left(25^{\circ} \mathrm{C}\right) \text { (Dumont et al. } 2011\right) \\
1.8\left(25^{\circ} \mathrm{C}\right)(\text { F. Heymes } 2005) \\
\left.6.9\left(25^{\circ} \mathrm{C}\right) \text { (Poddar et al. } 1996\right) \\
\left.12.1\left(45^{\circ} \mathrm{C}\right) \text { (Xia et al. } 1999\right) \\
\left.7.1\left(25,6^{\circ} \mathrm{C}\right) \text { (Poddar and Sirkar } 1996\right)\end{array}$ & $\begin{array}{c}\left.8.1\left(25^{\circ} \mathrm{C}\right) \text { (De Guardia } 1994\right) \\
17.7\left(25^{\circ} \mathrm{C}\right) \text { (Dumont et al. 2011) }\end{array}$ & $\begin{array}{c}2.1\left(25^{\circ} \mathrm{C}\right)(\text { De Guardia } 1994) \\
3.4\left(25^{\circ} \mathrm{C}\right) \text { (Dumont et al. 2011) }\end{array}$ \\
\hline $\begin{array}{c}2.16\left(25^{\circ} \mathrm{C}\right)(\text { F. Heymes } 2005) \\
1.41\left(25^{\circ} \mathrm{C}\right)(\text { F. Heymes } 2005) \\
1.51\left(25^{\circ} \mathrm{C}\right) \text { (Vuong et al. 2009) }\end{array}$ & $22.9\left(25^{\circ} \mathrm{C}\right)$ (Vuong et al. 2009) & $1.8\left(25^{\circ} \mathrm{C}\right)$ (Vuong et al. 2009) \\
\hline $14.3\left(30^{\circ} \mathrm{C}\right)$ (Poddar and Sirkar 1996) & & \\
\hline $\begin{array}{l}2.5\left(25^{\circ} \mathrm{C}\right) \text { (Vuong et al. 2009) } \\
1.5\left(25^{\circ} \mathrm{C}\right) \text { (Vuong et al. 2009) }\end{array}$ & $\frac{21.7\left(25^{\circ} \mathrm{C}\right) \text { (Vuong et al. 2009) }}{1.9\left(25^{\circ} \mathrm{C}\right) \text { (Vuong et al. 2009) }}$ & $\frac{1.7\left(25^{\circ} \mathrm{C}\right) \text { (Vuong et al. 2009) }}{6.9\left(25^{\circ} \mathrm{C}\right) \text { (Vuong et al. 2009) }}$ \\
\hline $29.4\left(22^{\circ} \mathrm{C}\right)$ (Césario et al. 1997b) & - & - \\
\hline $\begin{array}{l}417\left(22^{\circ} \mathrm{C}\right) \text { (Césario et al. 1997a) } \\
319\left(22^{\circ} \mathrm{C}\right) \text { (Césario et al. 1997a) } \\
245\left(22^{\circ} \mathrm{C}\right) \text { (Césario et al. 1997a) } \\
186\left(22^{\circ} \mathrm{C}\right) \text { (Césario et al. 1997a) }\end{array}$ & - & - \\
\hline
\end{tabular}


Table 6. Global mass transfer coefficient $K_{L} a\left(\mathrm{~s}^{-1}\right)$ in gas-liquid contactors containing various liquid absorbents

\begin{tabular}{|c|c|c|c|c|}
\hline \multirow[b]{2}{*}{ Solvents } & \multicolumn{4}{|c|}{ VOC } \\
\hline & Toluene & DMS & DMDS & References \\
\hline Water & $\begin{array}{c}{[7.8-8.3] 10^{-3}} \\
1.410^{-3} \\
1.810^{-2} \\
\end{array}$ & $4.010^{-3}$ & $1.810^{-3}$ & $\begin{array}{l}\text { (F. Heymes et al. 2007) } \\
\text { (Darracq et al. 2010c) } \\
\text { (Césario et al. 1997a) }\end{array}$ \\
\hline DEHA & $\begin{array}{c}2.510^{-4} \\
2.5110^{-4} \text { to } 2.4310^{-3}\end{array}$ & $4.6810^{-4}$ & $1.0410^{-4}$ & $\begin{array}{l}\text { (Vuong et al. 2009) } \\
\text { (F. Heymes et al. 2007) }\end{array}$ \\
\hline $\begin{array}{c}\text { DiEthylHexylPhtalate } \\
\text { Cables-bundle } \\
\text { Pall metal ring } \\
\end{array}$ & $\begin{array}{c}{[2.33-3.28] 10^{-4}} \\
3.110^{-4} \\
\end{array}$ & - & - & (Bourgois et al. 2009) \\
\hline Silicone oil (5 mPa.s) & $1.610^{-3}$ & $4.010^{-3}$ & $1.610^{-3}$ & (Darracq et al. 2010c) \\
\hline PEG 400 & {$[1.4-5.5] 10^{-4}$} & - & - & (F. Heymes et al. 2007) \\
\hline $\begin{array}{c}1 \text { to } 10 \% \text { vv of FC40 in } \\
\text { water }\end{array}$ & {$[1.6-2.0] 10^{-2}$} & - & - & (Césario et al. 1997a) \\
\hline $\begin{array}{c}\text { Silicone oil (53 } \\
\text { mPa.s)/water } \\
10 \% \mathrm{v} / \mathrm{v} \\
30 \% \mathrm{v} / \mathrm{v} \\
50 \% \mathrm{v} / \mathrm{v}\end{array}$ & $\begin{array}{l}1.610^{-4} \\
3.310^{-4} \\
1.610^{-4}\end{array}$ & - & - & (Rodriguez et al. 2001) \\
\hline
\end{tabular}


Table 7. VOC diffusion coefficients $D_{L}\left(\mathrm{~m}^{2} \cdot \mathrm{s}^{-1}\right)$ in various liquid absorbents

\begin{tabular}{|c|c|c|c|c|}
\hline \multirow[b]{2}{*}{ Solvents (viscosity) } & \multicolumn{4}{|c|}{ VOC } \\
\hline & Toluene & DMS & DMDS & References \\
\hline Water (1 mPa.s) & $8.210^{-10}\left(22^{\circ} \mathrm{C}\right)^{\mathrm{a}}$ & - & - & (Césario et al. 1997b) \\
\hline DEHA (12.5 mPa.s) & $8.6510^{-10}\left(25^{\circ} \mathrm{C}\right)$ & - & - & (F. Heymes et al. 2007) \\
\hline DIH Phtalate ${ }^{\mathrm{b}}$ (46 mPa.s) & $7.4310^{-11}\left(20^{\circ} \mathrm{C}\right)$ & & & \\
\hline DEH Phtalate $^{\mathrm{b}}$ (77 mPa.s) & $5.5110^{-11}\left(20^{\circ} \mathrm{C}\right)$ & - & - & (Bourgois et al. 2009) \\
\hline DIH Phtalate (55.0 mPa.s) & $1.9710^{-10}\left(25^{\circ} \mathrm{C}\right)$ & - & - & (F Heymes et al. 2006) \\
\hline DID Phtalate (118.8 mPa.s) & $0.9110^{-10}\left(25^{\circ} \mathrm{C}\right)$ & & & \\
\hline Silicone oil (5 mPa.s) & $5.6510^{-11}\left(25^{\circ} \mathrm{C}\right)$ & $5.1310^{-11}\left(25^{\circ} \mathrm{C}\right)$ & $8.7210^{-12}\left(25^{\circ} \mathrm{C}\right)$ & (Darracq et al. 2010c) \\
\hline Silicone oil (20 mPa.s) & $5.4610^{-10}\left(25^{\circ} \mathrm{C}\right)$ & - & - & (F Heymes et al. 2006) \\
\hline Silicone oil (50 mPa.s) & $7.6310^{-10}\left(26^{\circ} \mathrm{C}\right)$ & - & - & (Poddar et al. 1996) \\
\hline Silicone oil (50 mPa.s) & $2.6710^{-10}\left(25^{\circ} \mathrm{C}\right)$ & - & - & (Xia et al. 1999) \\
\hline Perfluorocarbon FC40 (4.5 mPa.s) & $7.210^{-10}\left(22^{\circ} \mathrm{C}\right)^{\mathrm{a}}$ & - & - & (Césario et al. 1997b) \\
\hline
\end{tabular}

${ }^{a}$ Estimated according to Wilke and Chang (Wilke and Chang 1955)

${ }^{b}$ di Di-2-EthylHexylPhthalate (DEHP), Di-Iso-HeptylPhthalate (DIHP) and Di-Iso-NonylPhthalate (DINP) 
Table 8. Elimination capacity (EC) of toluene in Two-Phase Partitioning Bioreactor (TPPB)

\begin{tabular}{cccc}
\hline $\begin{array}{c}\text { NAPL/water ratio } \\
(\% \mathrm{v} / \mathrm{v})\end{array}$ & Microorganisms & $\begin{array}{c}\mathrm{EC} \\
\left(\mathrm{g} \cdot \mathrm{m}^{-3} \cdot \mathrm{h}^{-1}\right)\end{array}$ & References \\
\hline 33\% Oleyl alcohol & Pseudomonas sp., & 79 & (Collins and Daugulis 1999c) \\
33\% n-Hexadecane & Alcaligenes xylosoxidans & 733 & (Daugulis and Boudreau 2003) \\
& Achromobacter xylosoxidans & $>326$ & (Boudreau and Daugulis 2006) \\
6\% 2-Undecanone & Pseudomonas putida & 197 & (Hamed et al. 2004) \\
$100 \%$ water & Mixed culture aquifer & 0.96 & (Alvarez and Vogel 1991) \\
& Pseudomonas sp. CFS-215 & 2.0 & \\
\hline
\end{tabular}


Table 9. Physicochemical properties of various NAPL extensively used in Two-phase Partitioning Bioreactor (TPPB)

\begin{tabular}{|c|c|c|c|c|c|c|}
\hline Name & Formula & Log Kow & Viscosity (Pa.s) & $\begin{array}{c}\text { Superficial } \\
\text { tension }(\mathrm{N} / \mathrm{m})\end{array}$ & $\begin{array}{l}\text { Solubility in water } \\
\qquad\left(\mathrm{g} . \mathrm{L}^{-1}\right)\end{array}$ & Biodegradability $^{a}$ \\
\hline Cyclohexane & $\mathrm{C}_{6} \mathrm{H}_{12}$ & 3.2 à 3.44 & $9.6610^{-4}$ & $2.5310^{-2}$ & 0.058 & $+($ Lee and Cho 2008) \\
\hline Hexane & $\mathrm{C}_{6} \mathrm{H}_{14}$ & 3.29 & $3.1010^{-4}$ & $1.8510^{-2}$ & 0.013 & $+($ Lee and Cho 2008 ) \\
\hline Ethylene glycol diehyl ether & $\mathrm{C}_{6} \mathrm{H}_{14} \mathrm{O}_{2}$ & 0.77 & $7.2710^{-4}$ & $2.4310^{-2}$ & $20.4 \%$ en volume & + \\
\hline Cyclooctene & $\mathrm{C}_{8} \mathrm{H}_{14}$ & 3.79 & $1.6610^{-3}$ & $2.9410^{-2}$ & - & + (Collins and Daugulis 1999a) \\
\hline Isooctane & $\mathrm{C}_{8} \mathrm{H}_{18}$ & 4.09 & $5.0710^{-4}$ & $1.8810^{-2}$ & Insoluble & $+($ Solano-Serena et al. 2004) \\
\hline Ethyl heptanoate & $\mathrm{C}_{9} \mathrm{H}_{18} \mathrm{O}_{2}$ & 3.4 & - & $2.7810^{-2}$ & 0.29 & + \\
\hline (+)-Limonene & $\mathrm{C}_{10} \mathrm{H}_{16}$ & 4.1 à 4.83 & - & - & $1.3810^{-2}$ & $\begin{array}{c}\text { + (Janikowski et al. 2002; Van } \\
\text { der Werf et al. 1999) }\end{array}$ \\
\hline 1-Decyne & $\mathrm{C}_{10} \mathrm{H}_{18}$ & 4.67 & $1.3210^{-3}$ & $2.6210^{-2}$ & - & + \\
\hline Decene & $\mathrm{C}_{10} \mathrm{H}_{20}$ & 5.19 & $8.2010^{-4}$ & $2.4810^{-2}$ & $1.4810^{-4}$ & + (Vieira et al. 2007) \\
\hline 2,6-dimethyl-2-octene & $\mathrm{C}_{10} \mathrm{H}_{20}$ & 5.02 & - & - & - & + (Fall et al. 1979) \\
\hline 2-Decanone & $\mathrm{C}_{10} \mathrm{H}_{20} \mathrm{O}$ & 3.2 to 3.7 & - & - & $7.6810^{-2}$ & + (Collins and Daugulis 1999a) \\
\hline Décane & $\mathrm{C}_{10} \mathrm{H}_{22}$ & 5.25 & $9.3010^{-4}$ & $2.3910^{-2}$ & - & $\begin{array}{l}\text { + (Fritsche W. and Hofrichter } \\
\text { M. 2005; Kester and Foster } \\
\text { 1963) }\end{array}$ \\
\hline 3,6-dimethyloctane & $\mathrm{C}_{10} \mathrm{H}_{22}$ & 5.1 to 5.9 & - & - & - & + (Fall et al. 1979) \\
\hline 1-decanol & $\mathrm{C}_{10} \mathrm{H}_{22} \mathrm{O}$ & 3.8 to 4.6 & $1.3910^{-2}$ & $2.8810^{-2}$ & Insoluble & + (Kester and Foster 1963) \\
\hline Dipentyl ether & $\mathrm{C}_{10} \mathrm{H}_{22} \mathrm{O}$ & 3.96 & $1.0810^{-3}$ & $2.4810^{-2}$ & Insoluble & + \\
\hline 2-Decanol & $\mathrm{C}_{10} \mathrm{H}_{22} \mathrm{O}$ & 3.9 & - & - & - & + (Collins and Daugulis 1999a) \\
\hline Jasmone & $\mathrm{C}_{11} \mathrm{H}_{16} \mathrm{O}$ & 3.55 to 4.1 & - & - & 0.168 & + (Collins and Daugulis 1999a) \\
\hline 2-Undecanone & $\mathrm{C}_{11} \mathrm{H}_{22} \mathrm{O}$ & 3.69 à 4.09 & - & - & $1.9710^{-2}$ & $\begin{array}{c}+ \text { (Fritsche W. and Hofrichter } \\
\text { M. 2005) }\end{array}$ \\
\hline Undecane & $\mathrm{C}_{11} \mathrm{H}_{24}$ & 5.74 & $1.2010^{-3}$ & $2.4710^{-2}$ & Insoluble & + (Kester and Foster 1963) \\
\hline 2-dodecanone & $\mathrm{C}_{12} \mathrm{H}_{24} \mathrm{O}$ & 4.4 & - & - & - & + (Collins and Daugulis 1999a) \\
\hline Dodecanal & $\mathrm{C}_{12} \mathrm{H}_{24} \mathrm{O}$ & 4.7 & $2.0410^{-3}$ & $2.9410^{-2}$ & Insoluble & $\begin{array}{c}+ \text { (Fritsche W. and Hofrichter } \\
\text { M. 2005) }\end{array}$ \\
\hline Dodecane & $\mathrm{C}_{12} \mathrm{H}_{26}$ & 6.23 & $1.1510^{-3}$ & $2.5410^{-2}$ & Insoluble $\left(3.6610^{-6}\right)$ & + (Sáez-Navarrete et al. 2008) \\
\hline Diethylsebacate & $\mathrm{C}_{14} \mathrm{H}_{26} \mathrm{O}_{4}$ & 4.33 & - & - & 0.08 & $\begin{array}{l}+ \text { (Nalli et al. 2006; Barnabe } \\
\text { et al. 2008) }\end{array}$ \\
\hline
\end{tabular}




\begin{tabular}{|c|c|c|c|c|c|c|}
\hline Tetradecane & $\mathrm{C}_{14} \mathrm{H}_{30}$ & 7.2 & $2.3410^{-3}$ & $2.6610^{-2}$ & Insoluble & $+($ Kester and Foster 1963) \\
\hline Farnesol & $\mathrm{C}_{15} \mathrm{H}_{26} \mathrm{O}$ & 5.4 & - & - & Insoluble & $\begin{array}{c}+ \text { (Berekaa and Steinbüch } \\
\text { 2000; Seubert 1960) }\end{array}$ \\
\hline Dibutylphtalate & $\mathrm{C}_{16} \mathrm{H}_{22} \mathrm{O}_{4}$ & 4.5 à 4.7 & $2.1310^{-2}$ & $3.3210^{-2}$ & 0.13 & + (Eaton and Ribbons 1982) \\
\hline Ethyl Myristate & $\mathrm{C}_{16} \mathrm{H}_{32} \mathrm{O}_{2}$ & 6.9 & - & - & Insoluble & + \\
\hline $\begin{array}{l}\text { HMN or } 2,2,4,4,6,8,8- \\
\text { heptamethylnonane }\end{array}$ & $\mathrm{C}_{16} \mathrm{H}_{34}$ & 7.79 & $3.7610^{-3}$ & $2.5310^{-2}$ & - & + (Rontani and Giusti 1986) \\
\hline n-Hexadecane & $\mathrm{C}_{16} \mathrm{H}_{34}$ & 8.2 & $1.1810^{-4}$ & $2.7610^{-2}$ & Insoluble & $\begin{array}{l}+ \text { (Fritsche W. and Hofrichter } \\
\text { M. 2005; Muñoz et al. 2006) }\end{array}$ \\
\hline Isopryl myristate & $\mathrm{C}_{17} \mathrm{H}_{34} \mathrm{O}_{2}$ & 7.17 & $5.6010^{-3}$ & $2.8010^{-2}$ & Insoluble & $\begin{array}{c}+ \text { (MacLeod and Daugulis } \\
\text { 2003) }\end{array}$ \\
\hline Linoleic Acid & $\mathrm{C}_{18} \mathrm{H}_{32} \mathrm{O}_{2}$ & 7.3 à 7.5 & $2.3110^{-2}$ & $3.2610^{-2}$ & Insoluble & $+($ Kester and Foster 1963) \\
\hline Octadecane & $\mathrm{C}_{18} \mathrm{H}_{34}$ & 9.18 & $3.8710^{-3}$ at $29^{\circ} \mathrm{C}$ & $2.7710^{-2}$ & Insoluble & $\begin{array}{c}+ \text { (Fritsche W. and Hofrichter } \\
\text { M. 2005) }\end{array}$ \\
\hline 1-Octadecene & $\mathrm{C}_{18} \mathrm{H}_{36}$ & 9.04 & $4.3110^{-3}$ & $2.8510^{-2}$ & Insoluble & + \\
\hline Olehyl alcohol & $\mathrm{C}_{18} \mathrm{H}_{36} \mathrm{O}$ & 7.5 & - & - & Insoluble & $\begin{array}{c}+ \text { (Fritsche W. and Hofrichter } \\
\text { M. 2005) }\end{array}$ \\
\hline Trihexylamine & $\mathrm{C}_{18} \mathrm{H}_{39} \mathrm{~N}$ & 7.4 à 7.8 & - & - & Insoluble & - \\
\hline Tridecylcyclohexane & $\mathrm{C}_{19} \mathrm{H}_{38}$ & 9.49 & - & - & Insoluble & $\begin{array}{c}+ \text { (Koma et al. 2003; Jimenez } \\
\text { and Bartha 1996; Koma et al. } \\
\text { 2001) }\end{array}$ \\
\hline Pristane & $\mathrm{C}_{19} \mathrm{H}_{40}$ & 9.38 & - & - & - & $\begin{array}{c}\text { + (Lee and Cho } 2008 \text {; Nhi- } \\
\text { Cong et al. 2009; Abed and } \\
\text { Köster 2005) }\end{array}$ \\
\hline Phytol & $\mathrm{C}_{20} \mathrm{H}_{40} \mathrm{O}$ & 8.3 à 9.1 & - & - & - & + (Rontani et al. 1999) \\
\hline Isophytol & $\mathrm{C}_{20} \mathrm{H}_{40} \mathrm{O}$ & 8.2 à 9.1 & - & - & Insoluble & + (Rontani et al. 1999) \\
\hline Di-2-ethylhexyl-adipate & $\mathrm{C}_{22} \mathrm{H}_{42} \mathrm{O}_{4}$ & 8.1 & $1.3810^{-2}$ & $3.0910^{-2}$ & Insoluble $\left(7.810^{-4}\right)$ & + (Barnabe et al. 2008) \\
\hline Cis-9-Tricosene & $\mathrm{C}_{23} \mathrm{H}_{46}$ & 11.42 & - & - & 0.0003 & $\begin{array}{c}+ \text { (Fritsche W. and Hofrichter } \\
\text { M. 2005) }\end{array}$ \\
\hline $\begin{array}{c}\text { Dioctyl phthalate/ } \\
\text { Di(2-ethylhexyl)phtalate }\end{array}$ & $\mathrm{C}_{24} \mathrm{H}_{38} \mathrm{O}_{4}$ & 7.6 à 8.39 & $7.4910^{-2}$ & $3.2610^{-2}$ & Insoluble $\left(2.710^{-4}\right)$ & $\begin{array}{c}\text { + (Barnabe et al. 2008; Liang } \\
\text { et al. 2008) }\end{array}$ \\
\hline Bis(ethylhexyl)sebacate & $\mathrm{C}_{26} \mathrm{H}_{50} \mathrm{O}_{4}$ & 10.08 & - & - & $<0.1$ & $\begin{array}{c}+ \text { (MacLeod and Daugulis } \\
\text { 2003) }\end{array}$ \\
\hline Squalene & $\mathrm{C}_{30} \mathrm{H}_{50}$ & 14.12 & - & - & Insoluble & + (Rontani J.F. et al. 2002) \\
\hline
\end{tabular}




\begin{tabular}{|c|c|c|c|c|c|c|}
\hline Squalane & $\mathrm{C}_{30} \mathrm{H}_{62}$ & 14.63 & $3.5010^{-2}$ & $2.9310^{-2}$ & - & $\begin{array}{c}\text { (Berekaa and Steinbüch } \\
\text { 2000) }\end{array}$ \\
\hline Trioctyl trimellitate & $\mathrm{C}_{33} \mathrm{H}_{54} \mathrm{O}_{6}$ & 11.59 & - & - & Insoluble & + \\
\hline $\begin{array}{c}\text { Silicone oil } \\
\text { 1-Poly-(dimethyl)-siloxane } \\
\text { 2-poly-(methylphenyl)-siloxane }\end{array}$ & $\begin{array}{l}\left(\mathrm{C}_{2} \mathrm{H}_{6} \mathrm{SiO}\right) \mathrm{n} / \\
\left(\mathrm{C}_{8} \mathrm{H}_{14} \mathrm{O}_{2} \mathrm{Si}_{2}\right) \mathrm{n}\end{array}$ & 2.6 to 4.25 & 0.005 to 0.2 & - & Insoluble & $\begin{array}{l}\text { - (Darracq et al. 2010c; Déziel } \\
\text { et al. 1999; Muñoz et al. } \\
\text { 2007; Quijano et al. 2009; } \\
\text { Guieysse et al. 2001; Ascon- } \\
\text { Cabrera and Lebeault 1995) }\end{array}$ \\
\hline Paraffin oil & 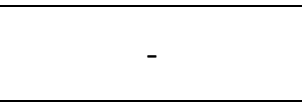 & - & - & - & Insoluble & $\begin{array}{c}\text { + (Oliveira and De França } \\
2005)\end{array}$ \\
\hline $\begin{array}{c}\text { Fluorocarbone } 40 \text { (43) } \\
\text { FC } 70 \\
\end{array}$ & $\begin{array}{c}\mathrm{C}_{9} \mathrm{~F}_{21} \mathrm{~N}\left(\mathrm{C}_{12} \mathrm{~F}_{27} \mathrm{~N}\right) \\
\mathrm{C}_{15} \mathrm{~F}_{33} \mathrm{~N} \\
\end{array}$ & $\begin{array}{l}(9.98) \\
12.88 \\
\end{array}$ & - & - & Insoluble & $\begin{array}{l}\text { - (Césario et al. 1997a; } \\
\text { Césario et al. 1997b) }\end{array}$ \\
\hline CO-1214 fatty Alcohol & $\begin{array}{c}\mathrm{CH}_{3}\left(\mathrm{CH}_{2}\right)_{\mathrm{n}-2} \mathrm{CH}_{2}-\mathrm{OH} \\
\mathrm{n}=10 \text { à } 12 \\
\end{array}$ & 5.2 & 0.012 at $30^{\circ} \mathrm{C}$ & - & Insoluble & $+($ Kester and Foster 1963) \\
\hline Corn oil & - & 7.4 & - & - & Insoluble & + (L. Singh et al. 2000) \\
\hline
\end{tabular}

a biodegradable, - non-biodegradable

${ }^{*}$ Cost according to Acros Organics 
Table 10. Critical log Kow for various microorganisms

\begin{tabular}{|c|c|c|c|}
\hline Microorganisms & Gram & Critical log Kow & References \\
\hline Bacillus OS-1906 & + & 2.0 & $\begin{array}{c}\text { (Sardessai and } \\
\text { Bhosle 2002) }\end{array}$ \\
\hline Arthrobacter S-1 & + & 2.0 & $\begin{array}{c}\text { (Sardessai and } \\
\text { Bhosle 2002) }\end{array}$ \\
\hline Pseudomonas putida S12 & - & 2.3 & $\begin{array}{c}\text { (Sardessai and } \\
\text { Bhosle 2002) }\end{array}$ \\
\hline Pseudomoans. aeruginosa LST-03 & - & 2.9 & $\begin{array}{c}\text { (Ogino et al. } \\
\text { 1999) }\end{array}$ \\
\hline Pseudomonas sp. ATCC 55595 & - & 3.1 & $\begin{array}{c}\text { (Collins and } \\
\text { Daugulis 1999b) }\end{array}$ \\
\hline Pseudomonas sp. ATCC 11172 & - & 3.3 & $\begin{array}{c}\text { (Vrionis et al. } \\
\text { 2002) }\end{array}$ \\
\hline Zymomonas mobilis & - & 4.0 & $\begin{array}{c}\text { (Bruce and } \\
\text { Daugulis 1991) }\end{array}$ \\
\hline Sphingomonas aromaticivorans B065 & - & 4.0 & $\begin{array}{c}\text { (Janikowski et al } \\
\text { 2002) }\end{array}$ \\
\hline Saccharomyces cerevisae & - & 5.7 & $\begin{array}{c}\text { (Bruce and } \\
\text { Daugulis 1991) }\end{array}$ \\
\hline Clostridium acetobutylicium & + & 6.0 & $\begin{array}{c}\text { (Bruce and } \\
\text { Daugulis 1991) }\end{array}$ \\
\hline Mycobacterium PYR-1 & + & 7.0 & $\begin{array}{l}\text { (MacLeod and } \\
\text { Daugulis 2003) }\end{array}$ \\
\hline
\end{tabular}

Table 11. Specific toluene partition coefficient between NAPL and water $\left(K_{N A P L / W}\right)$

\begin{tabular}{ccc}
\hline NAPL & $K_{N A P L / W}$ & References \\
\hline Fluorocarbon FC40 & 17.5 & (Césario et al. 1997b) \\
Octanol & 398 & (Muñoz et al. 2007) \\
Oleyl Alcohol & 405 & (Collins and Daugulis 1999a) \\
Dipentyl ether & 473 & (Collins and Daugulis 1999a) \\
2-Decanol & 745 & (Collins and Daugulis 1999a) \\
Jasmone & 1240 & (Collins and Daugulis 1999a) \\
2-Undecanone & 1304 & (Collins and Daugulis 1999a) \\
2-Decanone & 1384 & (Collins and Daugulis 1999a) \\
1-Decyne & 1587 & (Collins and Daugulis 1999a) \\
\hline
\end{tabular}


Table 12. Examples of bioreactor experiments involving polydimethylsiloxane (PDMS) either as an absorbent or a tank for pollutants.

\begin{tabular}{|c|c|c|c|c|c|}
\hline $\begin{array}{l}\text { Treatment } \\
\text { or process }\end{array}$ & Compounds & Microorganisms & Viscosity & Main conclusions & References \\
\hline Absorption & Oxygen & - & $25 \mathrm{mPa} . \mathrm{s}$ & $\begin{array}{l}\text { High solubility in PDMS and equilibrium solubility of the } \\
\text { same order of magnitude as hydrocarbons }\end{array}$ & (Cannon et al. 1960) \\
\hline $\begin{array}{l}\text { Two-phase } \\
\text { partitioning } \\
\text { bioreactor }\end{array}$ & $\begin{array}{l}\text { Di- and tri- } \\
\text { chlorobenzene } \\
\text { Ethylbutylaldéhyde } \\
\text { Ethyl butyrate } \\
\text { Ethanol } \\
\text { Ethyl acetate }\end{array}$ & $\begin{array}{l}\text { Mixed culture } \\
\text { (activated sludge) }\end{array}$ & $19 \mathrm{mPa} . \mathrm{s}$ & $\begin{array}{l}\text { Microbial growth on all substrate mixtures } \\
45 \% \text { biomass located at the oil/water interface around the } \\
\text { oil drops } \\
\text { Silicon oil non-biodegradable } \\
\text { Efficient system to remove toxic and hydrophobic } \\
\text { compounds }\end{array}$ & $\begin{array}{c}\text { (Ascon-Cabrera and } \\
\text { Lebeault 1993) }\end{array}$ \\
\hline $\begin{array}{l}\text { Two-phase } \\
\text { partitioning } \\
\text { bioreactor }\end{array}$ & $\begin{array}{l}\text { PAH: pyrene, } \\
\text { perylene, chrysene }\end{array}$ & Mixed culture & $\begin{array}{l}4.6 \mathrm{mPa} . \mathrm{s} \text { and } \\
19 \mathrm{mPa} . \mathrm{s}\end{array}$ & $\begin{array}{l}\text { Silicon oil is relevant for multiphase bioreactor (hydrophobic, } \\
\text { chemically stable and resistant to biodegradation) } \\
\text { Addition of surfactant is not interesting because they are } \\
\text { readily biodegradable leading to substrate competition. } \\
\text { Degradation principally occurs at the oil/water interface }\end{array}$ & $\begin{array}{l}\text { (Marcoux et al. } \\
\text { 2000) }\end{array}$ \\
\hline $\begin{array}{l}\text { Two-phase } \\
\text { partitioning } \\
\text { bioreactor }\end{array}$ & $\begin{array}{l}\text { Phenanthrene and } \\
\text { pyrene }\end{array}$ & $\begin{array}{c}\text { Mixture of } \\
\text { Pseudomonas sp } \\
\text { and Sphingomonas } \\
s p\end{array}$ & $2 \mathrm{mPa} . \mathrm{s}$ & $\begin{array}{l}\text { PDMS relevant for TPPB } \\
\text { Bacterial adhesion at the interface and improved } \\
\text { degradation rates } \\
\text { Two-phasic system improves the pollutant dispersion and } \\
\text { mass transfer between both liquid phases }\end{array}$ & $\begin{array}{l}\text { (Guieysse et al. } \\
\text { 2001) }\end{array}$ \\
\hline Biofiltration & Hexane & Activated sludge & $265 \mathrm{mPa} . \mathrm{s}$ & $\begin{array}{l}\text { Comparison between biofilters with and without PDMS. No } \\
\text { clear trend showed. }\end{array}$ & $\begin{array}{l}\text { (Fazaelipoor and } \\
\text { Shojaosadati 2002) }\end{array}$ \\
\hline Absorption & Oxygen & - & $4.6 \mathrm{mPa} . \mathrm{s}$ & $\mathrm{O}_{2}$ solubility in PDMS 8 times higher than in water & (Dumont et al. 2006) \\
\hline $\begin{array}{l}\text { Absorption } \\
\text { Two-phase } \\
\text { partitioning } \\
\text { bioreactor }\end{array}$ & Hexane & $\begin{array}{l}\text { Pseudomonas } \\
\text { aeruginosa }\end{array}$ & $19 \mathrm{mPa} . \mathrm{s}$ & $\begin{array}{l}\text { Hydrophobic compounds show a better affinity for PDMS } \\
\text { than for water. Addition of PDMS increases the process } \\
\text { performance (RE* and EC* five times higher than in the } \\
\text { absence of PDMS) } \\
\text { PDMS increases mass transfer in the gas-liquid contactor } \\
\text { PDMS has antifoaming properties leading to an absence of } \\
\text { foaming }\end{array}$ & (Muñoz et al. 2006) \\
\hline
\end{tabular}




\begin{tabular}{|c|c|c|c|c|c|}
\hline $\begin{array}{l}\text { Two-phase } \\
\text { partitioning } \\
\text { bioreactor }\end{array}$ & Pyrene & $\begin{array}{l}\text { Mycobacterium } \\
\text { frederiksbergense }\end{array}$ & & $\begin{array}{l}\text { Significant yield of degradation and lag time varied with the } \\
\text { initial concentration } \\
\text { Kinetic model for pyrene degradation is based on an } \\
\text { exponential growth }\end{array}$ & $\begin{array}{l}\text { (Mahanty et al. } \\
\text { 2008) }\end{array}$ \\
\hline $\begin{array}{l}\text { Absorption } \\
\text { Two-phase } \\
\text { partitioning } \\
\text { bioreactor }\end{array}$ & Isopropylbenzene & $\begin{array}{l}\text { Rhodococcus } \\
\text { erythropolis }\end{array}$ & $47.5 \mathrm{mPa} . \mathrm{s}$ & $\begin{array}{l}\text { The addition of a co-substrate (ethanol) in the bioreactor } \\
\text { enhances VOC removal }\end{array}$ & $\begin{array}{l}\text { (Aldric and Thonart } \\
\text { 2008) }\end{array}$ \\
\hline $\begin{array}{l}\text { Absorption } \\
\text { Two-phase } \\
\text { partitioning } \\
\text { bioreactor }\end{array}$ & $\begin{array}{l}\text { Isopropylbenzene } \\
\text { and Oxygen }\end{array}$ & - & $\begin{array}{l}9.4,96.4,336 \\
\text { and } 1300 \mathrm{mPa} . \mathrm{s}\end{array}$ & $\begin{array}{l}\text { Oxygen mass transfer decreases when silicon oil fraction } \\
\text { increases; if agitation speed and gas flow increase, } \mathrm{K}_{\mathrm{L}} \mathrm{a} \\
\text { increases. } \\
\text { Viscosity affect gas-liquid mass transfer }\end{array}$ & (Aldric et al. 2009a) \\
\hline
\end{tabular}


Table 13. Various anions in the structure of ionic liquids

\begin{tabular}{ccc}
\hline Anion & Name & Abbreviation \\
\hline $\mathrm{BF}_{4}^{-}$ & Tetrafluoroborate & {$\left[\mathrm{BF}_{4}\right]$} \\
$\mathrm{PF}_{6}^{-}$ & Hexafluorophosphate & {$\left[\mathrm{PF}_{6}\right]$} \\
$\mathrm{Cl}^{-}$ & Chloride & {$[\mathrm{Cl}]$} \\
$\mathrm{CH}_{3} \mathrm{CO}_{2}^{-}$ & Acetate & {$[\mathrm{Ac}]$} \\
$\mathrm{CF}_{3} \mathrm{CO}_{2}^{-}$ & Trifluoroacetate & {$[\mathrm{TFA}]$} \\
$\mathrm{CH}_{3} \mathrm{SO}_{4}^{-}$ & Methylsulfate & {$\left[\mathrm{MeSO}{ }_{4}\right]$} \\
$\mathrm{CF}_{3} \mathrm{SO}_{3}^{-}$ & Trifluoromethylsulfonate & {$\left[\mathrm{TFO}^{-}\right.$} \\
$\left(\mathrm{CF}_{3} \mathrm{SO}_{2}\right)_{2} \mathrm{~N}^{-}$ & Bis[(trifluoromethyl)sulfonyl]amide & {$\left[\mathrm{NTF}_{2}\right]$} \\
\hline
\end{tabular}


Table 14. Effects of the positive and negative ions on the physicochemical properties of ionic liquids (Huddleston et al. 2001; Matsumoto et al. 2004; Yang and Pan 2005; Zhao et al. 2007; Docherty et al. 2007)

\begin{tabular}{|c|c|c|c|}
\hline \multirow[t]{2}{*}{ Properties } & \multirow[t]{2}{*}{ Negative ions } & \multicolumn{2}{|l|}{ Positives ions } \\
\hline & & Base & Alkyl-chains R1 and R2 \\
\hline $\begin{array}{l}\text { Polarity and } \\
\text { solubility in water }\end{array}$ & $\mathrm{Cl}^{-}>\mathrm{I}^{-}>\mathrm{BF}_{4}^{-}>\mathrm{PF}_{6}>\mathrm{NTF}_{2}^{-}$ & $\begin{array}{c}\text { Alkylammonium }>\text { Pyrrolidinium }>\text { pyridinium } \\
\text { > imidazolium }\end{array}$ & -butyl >-hexyl > -octyl \\
\hline Toxicity & $\begin{array}{c}\text { Cytotoxic negative ions : }\left[\mathrm{C}_{12} \mathrm{H}_{8} \mathrm{BO}_{4}\right]^{-} \text {, } \\
{\left[\mathrm{PF}_{18} \mathrm{C}_{6}\right]^{-},\left[\mathrm{PF}_{24} \mathrm{C}_{9}\right]^{-},\left[\mathrm{NF}_{6} \mathrm{C}_{2}\right]^{-}, \mathrm{SbF}_{6}^{-}, \mathrm{Co}(\mathrm{CO})_{4}^{-}} \\
,\left[\mathrm{PF}_{10} \mathrm{C}_{4} \mathrm{O}_{2}\right]^{-},\left[\mathrm{NC}_{2} \mathrm{~F}_{6} \mathrm{~S}_{2} \mathrm{O}_{4}\right]^{-},\left[\mathrm{BC}_{4} \mathrm{O}_{8}\right]^{-} \text {et } \\
{\left[\mathrm{C}_{4} \mathrm{~S}_{3} \mathrm{~F}_{9} \mathrm{O}_{6}\right]^{-}}\end{array}$ & $\begin{array}{c}\text { Imidazolium }>\text { Pyridinium } \\
\text { then } \\
\text { Alkylphosphonium }>\text { Alkylammonium }\end{array}$ & -butyl $<-$ hexyl $<-$ octyl \\
\hline Surface tension & - & - & -butyl > -hexyl > -octyl \\
\hline Biodegradability & No specific effect & A little effect, pyridinium > imidazolium & $\begin{array}{l}\text {-butyl }<- \text {-hexyl }<\text {-octyl }<<< \\
\text { carbonyl or ester groups }\end{array}$ \\
\hline Biocompatibility & - & - & -butyl >-hexyl > -octyl \\
\hline
\end{tabular}

